\title{
Growth rates of nucleation mode particles in Hyytiälä during 2003-2009: variation with particle size, season, data analysis method and ambient conditions
}

\author{
T. Yli-Juuti ${ }^{1}$, T. Nieminen ${ }^{1}$, A. Hirsikko ${ }^{1}$, P. P. Aalto ${ }^{1}$, E. Asmi ${ }^{2}$, U. Hõrrak ${ }^{3}$, H. E. Manninen ${ }^{1}$, J. Patokoski ${ }^{1}$, \\ M. Dal Maso ${ }^{1}$, T. Petäjä ${ }^{1}$, J. Rinne ${ }^{1}$, M. Kulmala ${ }^{1}$, and I. Riipinen ${ }^{1,4}$ \\ ${ }^{1}$ Department of Physics, University of Helsinki, P.O. Box 64, 00014, University of Helsinki, Finland \\ ${ }^{2}$ Finnish Meteorological Institute, Erik Palménin aukio 1, 00560 Helsinki, Finland \\ ${ }^{3}$ Institute of Physics, University of Tartu, Ülikooli 18, 50090 Tartu, Estonia \\ ${ }^{4}$ Department of Applied Environmental Science and Bert Bolin Centre for Climate Research, Stockholm University, \\ 10691 Stockholm, Sweden
}

Received: 25 May 2011 - Published in Atmos. Chem. Phys. Discuss.: 28 July 2011

Revised: 21 November 2011 - Accepted: 7 December 2011 - Published: 20 December 2011

\begin{abstract}
The condensational growth rate of aerosol particles formed in atmospheric new particle formation events is one of the most important factors influencing the lifetime of these particles and their ability to become climatically relevant. Diameter growth rates (GR) of nucleation mode particles were studied based on almost $7 \mathrm{yr}$ of data measured during the years 2003-2009 at a boreal forest measurement station SMEAR II in Hyytiälä, Finland. The particle growth rates were estimated using particle size distributions measured with a Differential Mobility Particle Sizer (DMPS), a Balanced Scanning Mobility Analyzer (BSMA) and an Air Ion Spectrometer (AIS). Two GR analysis methods were tested. The particle growth rates were also compared to an extensive set of ambient meteorological parameters and trace gas concentrations to investigate the processes/constituents limiting the aerosol growth. The median growth rates of particles in the nucleation mode size ranges with diameters of $1.5-3 \mathrm{~nm}, 3-7 \mathrm{~nm}$ and $7-20 \mathrm{~nm}$ were $1.9 \mathrm{~nm} \mathrm{~h}^{-1}, 3.8 \mathrm{~nm} \mathrm{~h}^{-1}$, and $4.3 \mathrm{~nm} \mathrm{~h}^{-1}$, respectively. The median relative uncertainties in the growth rates due to the size distribution instrumentation in these size ranges were $25 \%, 19 \%$, and $8 \%$, respectively. For the smallest particles $(1.5-3 \mathrm{~nm})$ the AIS data yielded on average higher growth rate values than the BSMA data, and higher growth rates were obtained from positively charged size distributions as compared with negatively charged particles. For particles larger than $3 \mathrm{~nm}$ in diameter no such systematic differences were found. For these particles the uncertainty in the growth rate related to
\end{abstract}

Correspondence to: T. Yli-Juuti

(taina.yli-juuti@helsinki.fi)

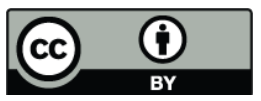

the analysis method, with relative uncertainty of $16 \%$, was similar to that related to the instruments. The growth rates of 7-20 nm particles showed positive correlation with monoterpene concentrations and their oxidation rate by ozone. The oxidation rate by $\mathrm{OH}$ did not show a connection with GR. Our results indicate that the growth of nucleation mode particles in Hyytiälä is mainly limited by the concentrations of organic precursors.

\section{Introduction}

New particle formation (NPF) by gas-to-particle-conversion followed by condensational growth of the freshly-formed nanoparticles is a frequently observed phenomenon in the atmosphere (e.g. Kulmala et al., 2004a). Recent studies suggest that these secondary aerosol particles form a notable fraction of atmospheric aerosol particle number concentrations (Spracklen et al., 2008; Merikanto et al., 2009) and therefore potentially have a substantial contribution in the effect of aerosol particles on climate. Atmospheric aerosol particles affect the Earth's climate in two ways. They scatter and absorb the solar radiation and thus have a direct effect on the Earth's radiation balance. Aerosol particles also have an indirect effect on the climate, as they can act as cloud condensation nuclei (CCN) and determine optical properties of the clouds and affect the cloud life time. Currently the effect of aerosols is the largest source of uncertainty in the estimation of the radiative forcing (Solomon et al., 2007).

(taina.yli-juuti@helsinki.fi)

Published by Copernicus Publications on behalf of the European Geosciences Union. 
The climatic effect of secondary aerosol particles formed by nucleation depends on their ability to survive during the growth up to the sizes where they can interact effectively with solar radiation or act as $\mathrm{CCN}$. This depends on the particle formation rate, i.e. the rate at which the new particles are nucleated, but also on the magnitude of the particle diameter growth rate (GR) to larger sizes relative to particle sinks, mainly coagulation to the pre-existing larger aerosol particles (Kerminen and Kulmala, 2002; Kerminen et al., 2004; Kulmala et al., 2005; Pierce and Adams, 2007; Kuang et al., 2009). Also, the potential health impacts of these particles depend on their size distribution and thus their condensational growth. Therefore, reliable presentation of the aerosol particle size distribution in atmospheric models requires correct consideration of the condensational growth of the particles. Particle growth rates derived from the atmospheric size distribution measurements give information on the concentrations and properties of the condensing vapours, and they can also be used in developing representations of gas-aerosol interactions for atmospheric models.

Particle growth rates have been estimated from atmospheric particle size distribution measurements with various methods. For instance, the time lag between the rise of concentration of sulphuric acid and the smallest detected particles has been used for estimating the growth rate at the very first steps (sub-3 nm) of particle growth (Weber et al., 1997; Sihto et al., 2006). The time evolution of the geometric mean size of the nucleation mode particles, typically obtained by fitting log-normal functions to the measured particle size distribution, has been used for obtaining the growth rate of the particles along their growth from 3-4 nm to Aitken mode size range (Dal Maso et al., 2005; Wehner et al., 2005). Recently, a number of studies have utilized a growth rate calculation method that is based on the estimation of time lags between maximum concentrations of different size particles in measured size distribution data (Hirsikko et al., 2005). This method provides information on the particle growth rate as a function of particle size and for the whole nucleation mode size range, if permitted by the detection limits of the size distribution measurement instrumentation. Also the measured size dependent charged fraction of particles has been used for calculating particle growth rate (Iida et al., 2008). In their recent study, Kuang et al. (2011) developed a GR calculation method that is based on the fitting of aerosol general dynamic equation to particle size distributions. With this method it is possible to decouple size and time dependence of particle growth rate. When using these various methods different assumptions have been made, and up to date there are still only few comparisons of the performance of the various growth rate estimation methods.

In previous studies it has been reported that the growth rates of atmospheric nucleation mode particles vary typically in the range $1-20 \mathrm{~nm} \mathrm{~h}^{-1}$ (Table 1; see also Kulmala et al., 2004a). Higher growth rates are sometimes observed at polluted sites (e.g. Iida et al., 2008), but short-time formation events of nanoparticles with very high growth rates (up to $50 \mathrm{~nm} \mathrm{~h}^{-1}$ ) have also been found e.g. at the northern background site Abisko (Svenningsson et al., 2008). At a number of sites GR is observed to increase as a function of particle size in the size range below $20 \mathrm{~nm}$ (Table 1). Exceptions have been observed at coastal regions and high altitude sites, where the lack of size-dependent increase in the growth rates is speculated to be due to inhomogeneities of condensable vapour source (Manninen et al., 2010).

Sulphuric acid has in many studies been found to be a key compound in atmospheric nucleation (Weber et al., 1995; Kulmala et al., 2006; Sihto et al., 2006; Riipinen et al., 2007; Kuang et al., 2008; Sipilä et al., 2010). However, observations suggest that its contribution to particle growth following the NPF is typically from a few percents to some tens of percents of the observed particle growth rate (Birmili et al., 2003; Boy et al., 2005; Fiedler et al., 2005; Stolzenburg et al., 2005; Smith et al., 2008; Kuang et al., 2010; Nieminen et al., 2010; Riipinen et al., 2011). Only in few cases gas phase concentration of sulphuric acid has been high enough for sulphuric acid to explain the observed condensational growth entirely (Birmili et al., 2003; Stoltzenburg et al., 2005; Yue et al., 2010). The fraction of condensational growth that can be explained by sulphuric acid has been observed to decrease with increasing particle size (Fiedler et al., 2005), even within sub-5 $\mathrm{nm}$ size range (Kuang et al., 2011). A substantial fraction of atmospheric sub-micrometer aerosol particle mass is found to consist of organic compounds (Tunved et al., 2006; Jimenez et al., 2009) and they can therefore be considered as the most probable candidates of the vapours responsible for the fraction of nucleation mode growth that is not explained by sulphuric acid. Additionally, many observations on the evolution of particle size distribution during NPF events support the importance of organic vapours on the particle growth. For example, at a boreal forest measurement station SMEAR II, Finland, nucleation mode particle growth rates are seen to increase during summer, which could be explained by the increased emissions of organic vapours from the vegetation (Dal Maso et al., 2005). Additionally, campaign-wise observations indicate a connection between nucleation mode growth and ambient concentrations of monoterpenes (Laaksonen et al., 2008) - which is a dominant group of volatile organic compounds (VOCs) emitted by boreal forests. Direct measurements of particle composition have shown that most of the growth of particles in nucleation and Aitken mode size ranges (10-33 nm) may be due to oxygenated and/or nitrogen containing organics such as amines (Allan et al., 2006; Smith et al., 2008, 2010; Barsanti et al., 2009), and indirect composition measurements suggest that significant fraction of also sub- $10 \mathrm{~nm}$ particle mass may be organic (O'Dowd et al., 2002; Kulmala et al., 2007a; Riipinen et al., 2009).

The comparison of the particle growth rates between the various studies, as well as analysis of the growth rates as a function of the particle size requires estimation of 
Table 1. Nucleation mode particle growth rates reported in some of the recent studies. Average (mean or median), range of GR and the size range for which the GR values were calculated are listed (if reported in the study).

\begin{tabular}{|c|c|c|c|c|c|c|}
\hline Reference & $\begin{array}{c}\text { Average } \\
\text { GR }\end{array}$ & Range of GR & Size range & Site & Site description & $\begin{array}{l}\text { Measurement } \\
\text { period }\end{array}$ \\
\hline \multirow[t]{3}{*}{ This study } & $1.9 \mathrm{~nm} \mathrm{~h}^{-1}$ & $0.3-13 \mathrm{~nm} \mathrm{~h}^{-1}$ & $1.5-3 \mathrm{~nm}$ & \multirow[t]{3}{*}{ Hyytiälä, Finland } & rural & \multirow[t]{3}{*}{ Apr 2003-Dec 2009} \\
\hline & $3.8 \mathrm{~nm} \mathrm{~h}^{-1}$ & $0.8-17 \mathrm{~nm} \mathrm{~h}^{-1}$ & $3-7 \mathrm{~nm}$ & & continental, & \\
\hline & $4.3 \mathrm{~nm} \mathrm{~h}^{-1}$ & $0.5-40 \mathrm{~nm} \mathrm{~h}^{-1}$ & $7-20 \mathrm{~nm}$ & & background & \\
\hline \multicolumn{2}{|l|}{ Asmi et al. (2011) } & $0.4-12 \mathrm{~nm} \mathrm{~h}^{-1}$ & $>7 \mathrm{~nm}$ & Pallas, Finland & $\begin{array}{l}\text { high-elevation, } \\
\text { remote } \\
\text { continental }\end{array}$ & Apr 2000-Dec 2010 \\
\hline \multirow[t]{3}{*}{ Boulon et al. (2010) } & & $2-7 \mathrm{~nm} \mathrm{~h}^{-1}$ & $1.3-3 \mathrm{~nm}$ & \multirow{3}{*}{$\begin{array}{l}\text { Jungfraujoch, } \\
\text { Switzerland }\end{array}$} & \multirow{3}{*}{$\begin{array}{l}\text { high altitude, } \\
\text { background }\end{array}$} & \multirow[t]{3}{*}{ Apr 2008-Apr 2009} \\
\hline & & $1-12 \mathrm{~nm} \mathrm{~h}^{-1}$ & $3-7 \mathrm{~nm}$ & & & \\
\hline & & $2-10 \mathrm{~nm} \mathrm{~h}^{-1}$ & $7-20 \mathrm{~nm}$ & & & \\
\hline Boy et al. (2008) & $4 \mathrm{~nm} \mathrm{~h}^{-1}$ & & $1-15 \mathrm{~nm}$ & $\begin{array}{l}\text { Rocky Mountains, } \\
\text { US }\end{array}$ & $\begin{array}{l}\text { remote } \\
\text { continental, } \\
\text { high altitude }\end{array}$ & Jun-Jul 2006 \\
\hline Cheung et al. (2011) & $4.6 \mathrm{~nm} \mathrm{~h}^{-1}$ & $1.8-7.8 \mathrm{~nm} \mathrm{~h}^{-1}$ & & Brisbane, Australia & urban & Jan-Dec 2009 \\
\hline \multirow[t]{2}{*}{ Fiedler et al. (2005) } & $7.7 \mathrm{nmh}^{-1}$ & $1.3-12 \mathrm{~nm} \mathrm{~h}^{-1}$ & $1-3 \mathrm{mn}$ & \multirow{2}{*}{$\begin{array}{l}\text { Heidelberg, } \\
\text { Germany }\end{array}$} & \multirow[t]{2}{*}{ polluted } & \multirow[t]{2}{*}{ Feb-Apr 2004} \\
\hline & $9.0 \mathrm{~nm} \mathrm{~h}^{-1}$ & $2.1-23 \mathrm{~nm} \mathrm{~h}^{-1}$ & $3-25 \mathrm{~nm}$ & & & \\
\hline Hamed et al. (2007) & $7 \mathrm{~nm} \mathrm{~h}^{-1}$ & $2.9-23 \mathrm{~nm} \mathrm{~h}^{-1}$ & & Po Valley, Italy & polluted & Mar 2002-Mar 2005 \\
\hline Iida et al. (2008) & $18 \mathrm{~nm} \mathrm{~h}^{-1}$ & $6-40 \mathrm{~nm} \mathrm{~h}^{-1}$ & $3.7-25 \mathrm{~nm}$ & Tecamac, Mexico & urban, polluted & Mar 2006 \\
\hline Kristensson et al. (2008) & $2.1 \mathrm{~nm} \mathrm{~h}^{-1}$ & $1.1-4.2 \mathrm{~nm} \mathrm{~h}^{-1^{\mathrm{a}}}$ & & Vavihill, Sweden & background & Feb 2001-May 2004 \\
\hline \multirow[t]{33}{*}{ Manninen et al. (2010) } & $3.8 \mathrm{nmh}^{-1}$ & $1.4-13 \mathrm{~nm} \mathrm{~h}^{-1}$ & $1.5-3 \mathrm{~nm}$ & \multirow{3}{*}{$\begin{array}{l}\text { Cabauw, } \\
\text { Netherlands }\end{array}$} & \multirow{3}{*}{$\begin{array}{l}\text { clean marine, } \\
\text { rural polluted }\end{array}$} & \multirow[t]{3}{*}{ Apr 2008-Mar 2009} \\
\hline & $5.5 \mathrm{~nm} \mathrm{~h}^{-1}$ & $1.4-37 \mathrm{~nm} \mathrm{~h}^{-1}$ & $3-7 \mathrm{~nm}$ & & & \\
\hline & $6.7 \mathrm{~nm} \mathrm{~h}^{-1}$ & $2.1-19 \mathrm{~nm} \mathrm{~h}^{-1}$ & $7-20 \mathrm{~nm}$ & & & \\
\hline & $2.7 \mathrm{~nm} \mathrm{~h}^{-1}$ & $1.0-5.0 \mathrm{~nm} \mathrm{~h}^{-1}$ & $1.5-3 \mathrm{~nm}$ & \multirow[t]{3}{*}{ Finokalia, Greece } & marine & \multirow[t]{3}{*}{ Apr 2008-Apr 2009} \\
\hline & $4.5 \mathrm{~nm} \mathrm{~h}^{-1}$ & $1.8-10 \mathrm{~nm} \mathrm{~h}^{-1}$ & $3-7 \mathrm{~nm}$ & & background, & \\
\hline & $4.4 \mathrm{~nm} \mathrm{~h}^{-1}$ & $1.8-20 \mathrm{~nm} \mathrm{~h}^{-1}$ & $7-20 \mathrm{~nm}$ & & coastal & \\
\hline & $4.8 \mathrm{~nm} \mathrm{~h}^{-1}$ & $1.5-18 \mathrm{~nm} \mathrm{~h}^{-1}$ & $1.5-3 \mathrm{~nm}$ & \multirow{3}{*}{$\begin{array}{l}\text { Hohenpeissenberg, } \\
\text { Germany }\end{array}$} & \multirow{3}{*}{$\begin{array}{l}\text { high-elevation, } \\
\text { backgound }\end{array}$} & Mar 2008-Feb 2009 \\
\hline & $4.2 \mathrm{~nm} \mathrm{~h}^{-1}$ & $2.2-12 \mathrm{~nm} \mathrm{~h}^{-1}$ & $3-7 \mathrm{~nm}$ & & & \\
\hline & $4.5 \mathrm{~nm} \mathrm{~h}^{-1}$ & $2.3-18 \mathrm{~nm} \mathrm{~h}^{-1}$ & $7-20 \mathrm{~nm}$ & & & \\
\hline & $3.7 \mathrm{~nm} \mathrm{~h}^{-1}$ & $1.3-7.5 \mathrm{~nm} \mathrm{~h}^{-1}$ & $1.5-3 \mathrm{~nm}$ & Jungfraujoch, & high-altitude, & Apr 2008-Apr 2009 \\
\hline & $7.2 \mathrm{~nm} \mathrm{~h}^{-1}$ & $2.4-12 \mathrm{~nm} \mathrm{~h}^{-1}$ & $3-7 \mathrm{~nm}$ & Switzerland & background & \\
\hline & $8.1 \mathrm{~nm} \mathrm{~h}^{-1}$ & $2.9-16 \mathrm{~nm} \mathrm{~h}^{-1}$ & $7-20 \mathrm{~nm}$ & & & \\
\hline & $3.4 \mathrm{~nm} \mathrm{~h}^{-1}$ & $1.2-8.0 \mathrm{~nm} \mathrm{~h}^{-1}$ & $1.5-3 \mathrm{~nm}$ & K-Puszta, Hungary & rural & Mar 2008-Feb 2009 \\
\hline & $5.1 \mathrm{~nm} \mathrm{~h}^{-1}$ & $1.2-14 \mathrm{~nm} \mathrm{~h}^{-1}$ & $3-7 \mathrm{~nm}$ & & continental, & \\
\hline & $5.2 \mathrm{~nm} \mathrm{~h}^{-1}$ & $1.6-20 \mathrm{~nm} \mathrm{~h}^{-1}$ & $7-20 \mathrm{~nm}$ & & background & \\
\hline & $5.5 \mathrm{~nm} \mathrm{~h}^{-1}$ & $4.1-6.0 \mathrm{~nm} \mathrm{~h}^{-1}$ & $1.5-3 \mathrm{~nm}$ & Mace Head, Ireland & marine & Jun 2008-May 2009 \\
\hline & $2.7 \mathrm{~nm} \mathrm{~h}^{-1}$ & $2.0-26 \mathrm{~nm} \mathrm{~h}^{-1}$ & $3-7 \mathrm{~nm}$ & & background, & \\
\hline & $5.4 \mathrm{~nm} \mathrm{~h}^{-1}$ & $2.7-10 \mathrm{~nm} \mathrm{~h}^{-1}$ & $7-20 \mathrm{~nm}$ & & coastal & \\
\hline & $2.6 \mathrm{~nm} \mathrm{~h}^{-1}$ & $1.1-13 \mathrm{~nm} \mathrm{~h}^{-1}$ & $1.5-3 \mathrm{~nm}$ & Melpitz, Germany & rural & Apr 2008-Apr 2009 \\
\hline & $5.7 \mathrm{~nm} \mathrm{~h}^{-1}$ & $2.4-17 \mathrm{~nm} \mathrm{~h}^{-1}$ & $3-7 \mathrm{~nm}$ & & polluted, & \\
\hline & $7.0 \mathrm{~nm} \mathrm{~h}^{-1}$ & $3.5-24 \mathrm{~nm} \mathrm{~h}^{-1}$ & $7-20 \mathrm{~nm}$ & & continental & \\
\hline & $3.8 \mathrm{~nm} \mathrm{~h}^{-1}$ & $1.3-8.2 \mathrm{~nm} \mathrm{~h}^{-1}$ & $1.5-3 \mathrm{~nm}$ & Pallas, Finland & high-elevation, & Apr 2008-Apr 2009 \\
\hline & $5.6 \mathrm{~nm} \mathrm{~h}^{-1}$ & $2.7-10 \mathrm{~nm} \mathrm{~h}^{-1}$ & $3-7 \mathrm{~nm}$ & & remote & \\
\hline & $3.8 \mathrm{~nm} \mathrm{~h}^{-1}$ & $3.0-6.3 \mathrm{~nm} \mathrm{~h}^{-1}$ & $7-20 \mathrm{~nm}$ & & continental & \\
\hline & $3.5 \mathrm{nmh}^{-1}$ & $1.2-41 \mathrm{~nm} \mathrm{~h}^{-1}$ & $1.5-3 \mathrm{~nm}$ & Puy de Dome, & high-elevation, & Apr 2008-May 2009 \\
\hline & $3.9 \mathrm{~nm} \mathrm{~h}^{-1}$ & $1.1-12 \mathrm{~nm} \mathrm{~h}^{-1}$ & $3-7 \mathrm{~nm}$ & France & background & \\
\hline & $5.7 \mathrm{~nm} \mathrm{~h}^{-1}$ & $2.2-17 \mathrm{~nm} \mathrm{~h}^{-1}$ & $7-20 \mathrm{~nm}$ & & & \\
\hline & $1.5 \mathrm{nmh}^{-1}$ & $0.9-3.1 \mathrm{~nm} \mathrm{~h}^{-1}$ & $1.5-3 \mathrm{~nm}$ & San Pietro & rural polluted, & Mar 2008-Oct 2008 \\
\hline & $4.2 \mathrm{~nm} \mathrm{~h}^{-1}$ & $1.6-9.2 \mathrm{~nm} \mathrm{~h}^{-1}$ & $3-7 \mathrm{~nm}$ & Capofiume, Italy & continental & \\
\hline & $7.5 \mathrm{~nm} \mathrm{~h}^{-1}$ & $3.6-16 \mathrm{~nm} \mathrm{~h}^{-1}$ & $7-20 \mathrm{~nm}$ & & & \\
\hline & $2.6 \mathrm{~nm} \mathrm{~h}^{-1}$ & $0.9-4.7 \mathrm{~nm} \mathrm{~h}^{-1}$ & $1.5-3 \mathrm{~nm}$ & Vavihill, Sweden & & Apr 2008-Feb 2009 \\
\hline & $3.2 \mathrm{~nm} \mathrm{~h}^{-1}$ & $1.5-5.8 \mathrm{~nm} \mathrm{~h}^{-1}$ & $3-7 \mathrm{~nm}$ & & background, & \\
\hline & $3.9 \mathrm{~nm} \mathrm{~h}^{-1}$ & $1.9-13 \mathrm{~nm} \mathrm{~h}^{-1}$ & $7-20 \mathrm{~nm}$ & & continental & \\
\hline
\end{tabular}


Table 1. Continued.

\begin{tabular}{|c|c|c|c|c|c|c|}
\hline Reference & $\begin{array}{c}\text { Average } \\
\text { GR }\end{array}$ & Range of GR & Size range & Site & Site description & $\begin{array}{l}\text { Measurement } \\
\text { period }\end{array}$ \\
\hline Modini et al. (2009) & $\begin{array}{c}2.1 \mathrm{~nm} \mathrm{~h}^{-1} \\
3.9 \mathrm{~nm} \mathrm{~h}^{-1} \\
19 \mathrm{~nm} \mathrm{~h}^{-1}\end{array}$ & $\begin{array}{r}0.4-6 \mathrm{~nm} \mathrm{~h}^{-1} \\
0.6-11 \mathrm{~nm} \mathrm{~h}^{-1} \\
3.6-43 \mathrm{~nm} \mathrm{~h}^{-1}\end{array}$ & $\begin{array}{r}1.5-3 \mathrm{~nm} \\
3-7 \mathrm{~nm} \\
7-20 \mathrm{~nm}\end{array}$ & $\begin{array}{l}\text { Agnes Water, } \\
\text { Australia }\end{array}$ & remote, coastal & Mar-Apr 2007 \\
\hline Neitola et al. (2011) & $2.4 \mathrm{~nm} \mathrm{~h}^{-1}$ & $0.5-4.5 \mathrm{~nm} \mathrm{~h}^{-1}$ & & Himalaya, India & rural, high altitude & Nov 2005-Jan 2010 \\
\hline Place et al. (2010) & $2.7 \mathrm{nmh}^{-1}$ & $0.9-5.5 \mathrm{~nm} \mathrm{~h}^{-1}$ & $6-60 \mathrm{~nm}$ & Durham, US & rural & Feb-Apr 2007 \\
\hline Stolzenburg et al. (2005) & $9.3 \mathrm{~nm} \mathrm{~h}^{-1}$ & $2.9-22 \mathrm{~nm} \mathrm{~h}^{-1}$ & $10-90 \mathrm{~nm}$ & Atlanta, US & urban & Jul-Aug 2002 \\
\hline Suni et al. (2008) & $\begin{array}{l}2.8 \mathrm{~nm} \mathrm{~h}^{-1} \\
4.1 \mathrm{~nm} \mathrm{~h}^{-1} \\
8.2 \mathrm{~nm} \mathrm{~h}^{-1}\end{array}$ & & $\begin{array}{r}1.5-3 \mathrm{~nm} \\
3-7 \mathrm{~nm} \\
7-20 \mathrm{~nm}\end{array}$ & $\begin{array}{l}\text { Tumbarumba, } \\
\text { Australia }\end{array}$ & $\begin{array}{l}\text { rural, } \\
\text { continental }\end{array}$ & Jul 2005-Oct 2006 \\
\hline Svenningsson et al. (2008) & & $0.5-10 \mathrm{~nm} \mathrm{~h}^{-1^{\mathrm{b}}}$ & & Abisko, Sweden & $\begin{array}{l}\text { subarctic, } \\
\text { remote }\end{array}$ & Jul 2005-Sep 2006 \\
\hline Vakkari et al. (2011) & $\begin{array}{l}6.2 \mathrm{~nm} \mathrm{~h}^{-1} \\
8.0 \mathrm{~nm} \mathrm{~h}^{-1} \\
8.1 \mathrm{~nm} \mathrm{~h}^{-1}\end{array}$ & $\begin{array}{l}1.4-31 \mathrm{~nm} \mathrm{~h}^{-1} \\
1.3-60 \mathrm{~nm} \mathrm{~h}^{-1} \\
2.0-29 \mathrm{~nm} \mathrm{~h}^{-1}\end{array}$ & $\begin{array}{r}1.5-3 \mathrm{~nm} \\
3-7 \mathrm{~nm} \\
7-20 \mathrm{~nm}\end{array}$ & $\begin{array}{l}\text { Botsalano, Republic } \\
\text { of South Africa }\end{array}$ & semi-clean & Jul 2006-Feb 2008 \\
\hline Venzac et al. (2008) & $1.8 \mathrm{~nm} \mathrm{~h}^{-1}$ & & & Himalaya, Nepal & high altitude & Feb-Mar 2007 \\
\hline Virkkula et al. (2007) & $\begin{array}{l}1.1 \mathrm{~nm} \mathrm{~h}^{-1} \\
1.9 \mathrm{~nm} \mathrm{~h}^{-1} \\
3.9 \mathrm{~nm} \mathrm{~h}^{-1}\end{array}$ & $\begin{array}{l}0.9-2.1 \mathrm{~nm} \mathrm{~h}^{-1} \\
1.0-9.1 \mathrm{~nm} \mathrm{~h}^{-1} \\
2.0-4.3 \mathrm{~nm} \mathrm{~h}^{-1}\end{array}$ & $\begin{array}{r}1.3-3 \mathrm{~nm} \\
3-7 \mathrm{~nm} \\
7-20 \mathrm{~nm}\end{array}$ & Aboa, Antarctica & remote & Dec 2004-Jan 2005 \\
\hline Wehner et al. (2005) & & $2-8 \mathrm{~nm} \mathrm{~h}^{-1}$ & $3-25 \mathrm{~nm}$ & Melpitz, Germany & rural & Summer 2003 \\
\hline Wu et al. (2007) & & $0.1-11 \mathrm{~nm} \mathrm{~h}^{-1}$ & & Beijing, China & urban, polluted & Mar 2004-Feb 2005 \\
\hline Yli-Juuti et al. (2009) & $\begin{array}{l}1.7 \mathrm{~nm} \mathrm{~h}^{-1} \\
4.1 \mathrm{~nm} \mathrm{~h}^{-1} \\
6.3 \mathrm{~nm} \mathrm{~h}^{-1}\end{array}$ & $\begin{array}{c}1.0-4.6 \mathrm{~nm} \mathrm{~h}^{-1} \\
1.4-8.6 \mathrm{~nm} \mathrm{~h}^{-1} \\
2.2-24 \mathrm{~nm} \mathrm{~h}^{-1}\end{array}$ & $\begin{array}{r}1.5-3 \mathrm{~nm} \\
3-7 \mathrm{~nm} \\
7-20 \mathrm{~nm}\end{array}$ & K-Puszta, Hungary & $\begin{array}{l}\text { rural } \\
\text { continental, } \\
\text { background }\end{array}$ & May-Jun 2006 \\
\hline
\end{tabular}

a 10 th and 90th percentile.

b Occasionally (at night time) higher GRs up to $50 \mathrm{~nm} \mathrm{~h}^{-1}$.

the accuracy of the determined growth rates, information which is rarely found in publications. Furthermore, although information on the seasonal patterns of particle growth rates exists (e.g. Birmili et al., 2003; Dal Maso et al., 2005), so far there have not been long term studies on the particle growth as a function of the particle size and comprehensive comparison of size-separated growth rates to other ambient data.

In this paper, the size-dependent growth rates of nucleation mode particles are estimated using almost seven years of particle size distribution measurement data from a boreal forest site recorded with three different instruments and applying two commonly-used growth rate calculation methods (Hirsikko et al., 2005; Dal Maso et al., 2005). The specific aims of this work are (1) to study the inter-annual and seasonal variation in the aerosol particle growth rates as a function of the particle size, (2) to examine the uncertainty of GR values estimated from aerosol number size distribution data and (3) to investigate the connection of these growth rates to ambient conditions to find the most important processes limiting particle growth in Hyytiälä. To develop parameterizations of aerosol growth that are usable in large scale atmospheric models requires knowledge on the factors that determine and limit the particle growth: even though the actual condensing vapours are not identified, it is of benefit to know which factors determine the rate at which particles can grow in the atmosphere.

First, the change in the growth rate as a function of the size of the particles, as well as the seasonal and annual variations of the growth rates are studied based on the long dataset. Second, the uncertainty of the calculated growth rates is investigated comparing the two growth rate calculation methods and growth rates obtained from data measured with the three different instruments. Third, the growth rates of the particles are compared to an extensive set of meteorological and trace gas concentration data to study which conditions favour or hinder the particle growth and investigate which processes limit nucleation mode growth in Hyytiälä. Here, basic meteorological data is used to study the role of general ambient conditions on the particle growth rates. The most important of these variables are temperature due to its connection to emissions of VOCs and saturation vapour pressures of condensable vapours, and UVB radiation due to its connection to oxidation in the atmosphere. Furthermore, the concentrations of monoterpenes, as well as their oxidation rates, are compared to the observed nucleation mode growth. For completeness the growth rates are also compared to inorganic gas 
concentrations. It is also tested whether the sink for condensing vapour caused by larger pre-existing aerosol particles limits the nucleation mode particle growth. The processes and their connection to the long-term data sets of meteorological parameters are outlined in Fig. 1.

\section{Measurements and methods}

\subsection{Measurements}

The measurements were carried out at SMEAR II station situated in Hyytiälä, southern Finland $\left(61^{\circ} 51^{\prime} \mathrm{N}, 24^{\circ} 17^{\prime} \mathrm{E}\right.$, 181 m a.s.l.) during the period from April 2003 to December 2009. SMEAR II is a background site in the boreal forest zone and the surroundings of the station are dominated by Scots pine (Hari and Kulmala, 2005).

The core of the dataset used in this study are the charged and total particle size distributions measured with a Differential Mobility Particle Sizer (DMPS), a Balanced Scanning Mobility Analyzer (BSMA) and an Air Ion Spectrometer (AIS). During the measurement period of 81 months the measurements with the DMPS and the BSMA were continuous whereas AIS was measuring from April 2003 until June 2007 with measurement breaks during 15 April 2003-10 August 2003, 17 May 2006-9 August 2006, and 16 September 2006-9 January 2007. The instruments were located in different cabins at the SMEAR II site. All the instruments sampled under the canopy.

\subsubsection{DMPS}

The Differential Mobility Particle Sizer (DMPS) measures the total particle concentration size distribution including both neutral and charged particles. In brief, a DMPS has a bipolar charger to charge the aerosol particle population to the equilibrium charge distribution, a DMA (Differential Mobility Analyzer) to sample one size fraction of particles at a time, and a CPC (Condensation Particle Counter) to measure the particle number concentration. The DMPS setup used at Hyytiälä consists of two DMPSs, each having one cylindrical DMA and one CPC. The detection limits of the CPCs are $3 \mathrm{~nm}$ and $10 \mathrm{~nm}$ and the two DMPSs have partly overlapping size range to enable detection of particles of 3$1000 \mathrm{~nm}$ (3-500 nm until December 2004) in diameter (Aalto et al., 2001; Dal Maso et al., 2005). This size range is divided into 38 logarithmically distributed size sections and one size distribution is measured in $10 \mathrm{~min}$. The continuous sheath flow in DMPS goes through a diffusion dryer and, therefore, DMPS measures the dry size of the particles (with sheath flow $\mathrm{RH}<30 \%$ ). In the beginning of the measurement period the sample was taken at $2 \mathrm{~m}$ above the ground. In September 2004 DMPS was moved to a new measurement cabin and since then the sampling height has been $8 \mathrm{~m}$ above the ground.

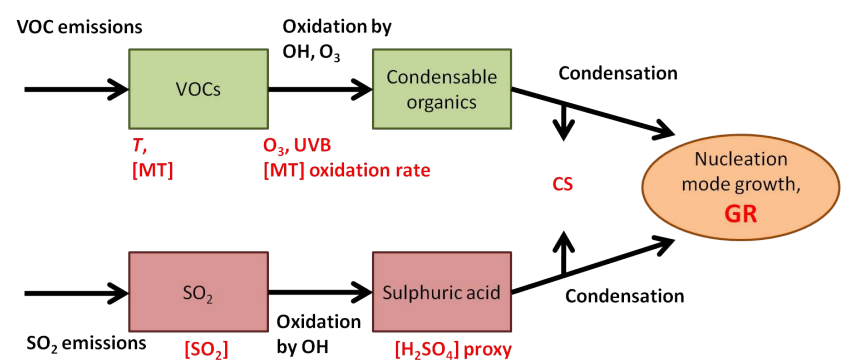

Fig. 1. A schematic connecting the studied long-term datasets of atmospheric parameters (temperature $T, \mathrm{O}_{3}, \mathrm{UVB}$ radiation, monoterpene concentrations MT, condensation sink CS, $\mathrm{SO}_{2}$, sulphuric acid proxy, in bold red) to the concentrations of VOCs and $\mathrm{SO}_{2}$, and the processes (emission, oxidation, condensation, in bold black) leading to nucleation mode particle growth rates (GR).

\subsubsection{BSMA}

The Balanced Scanning Mobility Analyzer (BSMA, manufactured by AIREL Ltd, Estonia) measures the size distribution of charged particles and small ions in atmospheric air (Tammet, 2006). It is a single-channel differential aspiration spectrometer, which consists of two parallel plate DMAs, one for measuring positively and one for negatively charged particles, connected with electrometric unit as a balanced capacitance bridge. Concentration of particles is calculated from the electric current generated by the charged particles deposited on the collector placed on the outer DMA plate. The electric mobility distribution of charged particles is obtained by applying a driving high voltage to the mobility analyzer and continuously scanning through the mobility range $0.032-3.2 \mathrm{~cm}^{2} \mathrm{~V}^{-1} \mathrm{~s}^{-1}$, which corresponds to particle sizes of 0.8-7.5 nm in Millikan diameter (Mäkelä et al., 1996). The electric mobility range is divided into 16 logarithmically uniform fractions. The BSMA measures positively and negatively charged particles by turns. The measuring cycle of the BSMA was six minutes (three minutes per polarity) until 15 August 2005. In order to reduce the fluctuation in the data, the original $6 \mathrm{~min}$ averaged data was converted into $15 \mathrm{~min}$ format by calculating arithmetic averages of the data points falling in the quarters of an hour. From the mid of August 2005 the BSMA measured in ten minute cycles. BSMA measured at $70 \mathrm{~m}$ (20 m until September 2004) distance from the DMPS and the sample was taken at $1.6 \mathrm{~m}$ above the ground.

\subsubsection{AIS}

The Air Ion Spectrometer (AIS, manufactured by AIREL Ltd., Estonia) measures the size distribution of naturally charged particles (Mirme et al., 2007). This device has two cylindrical DMAs, one for each polarity of particles. The outer electrodes of the mobility analyzers consist of insulated sections, each connected to individual electrometer 
(21 electrometers per polarity). The charged particles are classified inside the mobility analyzer according to their electrical mobility and deposited onto these insulated sections. This enables the simultaneous measurement of particles of different sizes and both polarities with a high time resolution. The AIS divides detected mobility range $0.0013-3.2 \mathrm{~cm}^{2} \mathrm{~V}^{-1} \mathrm{~s}^{-1}$ into 28 logarithmically uniformly distributed fractions. This mobility range corresponds to $0.8-40 \mathrm{~nm}$ in Millikan diameter. The time resolution of the size distribution measurements with the AIS was set to 5 min. The AIS measured at the same location as the BSMA with sampling height of $1.6 \mathrm{~m}$ above the ground until September 2004. After this the AIS was measuring at the same location as the DMPS and the sample was taken at $3 \mathrm{~m}$ above the ground.

\subsubsection{Meteorological data, gas concentrations and condensation sink}

In addition to aerosol size distribution data, basic meteorological data (temperature, radiation, relative humidity, pressure and wind speed) and trace gas concentrations $\left(\mathrm{H}_{2} \mathrm{O}\right.$, $\mathrm{SO}_{2}, \mathrm{NO}, \mathrm{NO}_{\mathrm{x}}, \mathrm{CO}_{2}, \mathrm{CO}$ ) measured at the station at $16.8 \mathrm{~m}$ height were used in the analysis (for the list of instruments, see Kulmala et al., 2001). For the years 2007-2009 also monoterpene concentrations measured with a Proton Transfer Reaction Mass Spectrometer (PTR-MS, Ionicon Analytik $\mathrm{GmbH}$, Lindinger et al., 1998, de Gouw et al., 2007) at $14 \mathrm{~m}$ above ground were utilized in the analysis (Taipale et al., 2008). Additionally, data on oxidation related gas phase species $\mathrm{O}_{3}$, measured with TEI 49 ozone analyzer (Thermo Environmental Instruments, Inc., USA) during 2003-2009 at $16.8 \mathrm{~m}$ above the ground, and $\mathrm{OH}$, measured with a Chemical Ionization Mass Spectrometer CIMS (Petäjä et al., 2009) during spring 2007 at $1.5 \mathrm{~m}$ above the ground, were included in the analysis.

Concentrations of a group of biogenic volatile organic compounds (BVOC), including monoterpenes, have been shown to depend exponentially on the temperature at SMEAR II (Lappalainen et al., 2009). Therefore, to extend the time series of monoterpene concentration data in the analysis, the monoterpene concentration was approximated with the parameterisation (see Fig. 1)

$[\mathrm{MT}]_{\mathrm{model}}=a \cdot \exp (b \cdot T)$

where $a=0.062$ and $b=0.078$ - which has been shown to reproduce observations of monoterpene concentrations in Hyytiälä with good accuracy (Lappalainen et al., 2009).

Also oxidation rates of monoterpenes, i.e. production rates of oxidation products of monoterpenes, by $\mathrm{OH}$ and $\mathrm{O}_{3}$ were utilised in the analysis. The $\mathrm{OH}$ concentration data was available for two months from the spring 2007 (Petäjä et al., 2009) and for this period the oxidation rates were calculated from measured monoterpene, $\mathrm{OH}$ and $\mathrm{O}_{3}$ concentrations ([MT], $[\mathrm{OH}]$ and $\left.\left[\mathrm{O}_{3}\right]\right)$ with

$[\mathrm{OR}]_{\mathrm{OH}}=k_{\mathrm{OH}} \cdot[\mathrm{OH}] \cdot[\mathrm{MT}]$

and

$[\mathrm{OR}]_{\mathrm{O}_{3}}=k_{\mathrm{O}_{3}} \cdot\left[\mathrm{O}_{3}\right] \cdot[\mathrm{MT}]$

where the rate constants are $k_{\mathrm{OH}}=7.5 \times 10^{-11} \mathrm{~cm}^{3}$ molecules ${ }^{-1} \mathrm{~s}^{-1}$ and $k_{\mathrm{O}_{3}}=1.4 \times 10^{-17} \mathrm{~cm}^{3}$ molecules $^{-1} \mathrm{~s}^{-1}$. The rate constants $k_{\mathrm{OH}}$ and $k_{\mathrm{O}_{3}}$ were calculated as weighted averages of the reaction coefficients of individual monoterpenes typical for SMEAR II according to Hakola et al. (2003). The temperature dependence of $k_{\mathrm{OH}}$ and $k_{\mathrm{O}_{3}}$ was ignored as this was not considered to cause significant uncertainty compared to other factors. To have longer time series of also the oxidation rates of monoterpenes, simple model calculations for the oxidation rates were made using the UVB radiation intensity, concentration of $\mathrm{O}_{3}$ and the modelled monoterpene concentration. For the first approximation the concentration of $\mathrm{OH}$-radicals depends on UVB radiation intensity (Rohrer and Berresheim, 2006; Petäjä et al., 2009) and, therefore, the oxidation rates of monoterpenes can be approximated as

$[\mathrm{OR}]_{\mathrm{OH}, \text { model }}=C_{1} \cdot \mathrm{UVB} \cdot[\mathrm{MT}]_{\mathrm{model}}$

and

$[\mathrm{OR}]_{\mathrm{O}_{3} \text {,model }}=C_{2} \cdot\left[\mathrm{O}_{3}\right] \cdot[\mathrm{MT}]_{\text {model }}$

where $C_{1}$ and $C_{2}$ are constants, for which the values were found by fitting the modelled oxidation rates to the measurement-based oxidation rates obtained from Eqs. (2) and (3) (see also Fig. 1).

To study the connection of nucleation mode growth to ambient sulphuric acid, a semi-empirical proxy for sulphuric acid concentration was calculated based on the $\mathrm{SO}_{2}$ concentration, UVB radiation intensity and condensation sink of sulphuric acid (CS) by (Petäjä et al., 2009)

$\left[\mathrm{H}_{2} \mathrm{SO}_{4}\right]=k_{\mathrm{H}_{2} \mathrm{SO}_{4}} \cdot \frac{\left[\mathrm{SO}_{2}\right] \cdot \mathrm{UVB}}{\mathrm{CS}}$

where $k_{\mathrm{H}_{2} \mathrm{SO}_{4}}=8.4 \times 10^{-7} \times \mathrm{UVB}^{-0.68} \mathrm{~m}^{2} \mathrm{~W}^{-1} \mathrm{~s}^{-1}$ and the loss of the sulphuric acid vapour is described by CS.

Condensation sink describes the loss rate of the condensable vapours onto the pre-existing aerosol particles (Pirjola et al., 1999). It was calculated based on size distribution measured with DMPS using

$\mathrm{CS}=2 \pi D \sum_{i} \beta_{\mathrm{m}}\left(D_{\mathrm{p}, i}\right) D_{p, i} N_{i}$

where $D$ is the vapour diffusion coefficient, $D_{\mathrm{p}, i}$ is the diameter of particles in the size class $i$ and $N_{i}$ is the number concentration of these particles. For calculating the CS the dry size distribution measured with DMPS was converted into the ambient distribution using the parameterization by 
Laakso et al. (2004). The transition regime correction factor for mass transfer $\beta_{\mathrm{m}}$ was calculated with the expression by Fuchs and Sutugin (1970) using a value of 1 for mass accommodation coefficient. When calculating CS the vapour was assumed to have molecular properties of sulphuric acid, and a negligible saturation vapour pressure. The condensation sink is of interest when analysing NPF events as it describes how fast the vapour is removed by the existing aerosol particles. It has been found that at SMEAR II low CS favours particle formation (Hyvönen et al., 2005). High condensation sink might suppress the particle formation and the growth of the newly formed particles as substantial fraction of the vapours could be condensing on the larger particles. Furthermore, condensation sink is proportional to coagulation sink of nucleation mode particles on pre-existing particles and, therefore, high CS might imply that high growth rate is required for the newly formed particles to survive and grow to larger sizes instead of being scavenged by coagulation (Kulmala et al., 2005).

The particle growth rates were compared to meteorological data, inorganic trace gas concentrations, measured monoterpene concentration, measurement based and modelled oxidation rates of monoterpenes, proxy for sulphuric acid concentration and condensation sink. Meteorological data is utilized in studying the effect of general ambient conditions to the particle growth. The most important of these variables are temperature, due to its effect on VOC emissions and saturation vapour pressures and thereby on concentrations and the condensation rates of vapours on the particles, and UVB radiation, due to its role on the oxidation process of gas phase compounds in the atmosphere. For completeness, also inorganic trace gas $\left(\mathrm{NO}, \mathrm{NO}_{\mathrm{x}}, \mathrm{CO}, \mathrm{CO}_{2}\right.$ and $\left.\mathrm{SO}_{2}\right)$ concentrations are considered.

\subsection{Methods for determining the nucleation mode growth rate}

\subsubsection{Method of maximum concentrations}

Size-dependent growth rates (GR) of nucleation mode particles were calculated using the "maximum concentration" method (Lehtinen et al., 2003; Hirsikko et al., 2005). In this method the evolution of the measured particle size distribution during a NPF event is examined starting from the first size fractions where the new particles are detected, and the moment when the concentration of particles reaches maximum value in each size fraction is determined. This is done by fitting a normal distribution curve in the concentration time series during the NPF event and finding the moment when this curve has its maximum. The normal distribution curve is fitted to reduce the effect of noise in the measured data. When the particles are formed, a peak in the concentration time series of the smallest particles, around $1.5 \mathrm{~nm}$ in diameter, is seen at first. Later during the day, as the particles grow, peaks in the concentration time series in the size fractions of larger particles are observed. GR is obtained as the slope of a line fitted in the data pairs of the determined moment of maximum concentration and geometric mean diameter of the particles of the corresponding size fraction. The line was fitted in three size ranges corresponding to Millikan diameters $1.5-3 \mathrm{~nm}, 3-7 \mathrm{~nm}$ and 7-20 $\mathrm{nm}$ of particles. The lowest size limit at $1.5 \mathrm{~nm}$ is due to the small ion mode that is continuously present in the size distributions measured with the AIS and the BSMA (Hirsikko et al., 2005, 2011; Kulmala et al., 2007b) and makes it often impossible to distinguish the growing mode at the smaller sizes. The upper limit at $20 \mathrm{~nm}$ is due to the tendency of the peak in the concentration time series to widen at the larger sizes. Limits at $3 \mathrm{~nm}$ and $7 \mathrm{~nm}$ are due to lower detection limit of the DMPS and upper detection limit of the BSMA, respectively. Due to the detection limits the $1.5-3 \mathrm{~nm}$ size range was not applied to the DMPS data whereas the $7-20 \mathrm{~nm}$ size range was not applied to the BSMA data. Therefore, taking into account that the measurements were done with three spectrometers and the AIS and the BSMA measure separately the size distributions of positively and negatively charged particles, for each event there were at maximum four, five and three GR values calculated in the size ranges of $1.5-3 \mathrm{~nm}, 3-7 \mathrm{~nm}$ and $7-20 \mathrm{~nm}$, respectively. In practise, it was not possible to obtain the GR values from every instrument and for each of the size ranges for every NPF event. For the DMPS data this method was additionally applied for the size range of 3 $20 \mathrm{~nm}$ for the purpose of comparing the two GR calculation methods.

The GR calculated with this method represents the observed average diameter change rate of the nucleation mode particle population. This is not necessarily the same as the growth rate of individual particles caused by condensation of vapours as there are also other processes than condensation, mainly coagulation, affecting the particle size distribution (Stolzenburg et al., 2005). The GR calculation method described above has two main sources of uncertainty. First, air mass changes may cause fluctuations in the time series of concentration which interfere with the growth rate estimation. A sudden change of air mass typically causes the calculated GR to be far too high. This is because the peaks in the concentration time series are in these situations narrower than would be expected if the same air mass could be sampled. Second, in some cases with fluctuation in the growing nucleation mode there may be more than one peak appearing in the time series of the concentration in some of the size channels. In these cases it is not always clear which peak should be chosen and, therefore, the method is also prone to subjective errors. Both of these sources of uncertainty are related to time-dependent processes. Since the particles are considered one size fraction at a time, this method is less sensitive to size dependent processes, like coagulation. However, if the GR is low and there is a substantial coagulation sink for the nucleation mode particles, and if the magnitude of the sink changes significantly during the growth time, this 
GR calculation method may fail as the moments of maximum concentration would be shifted in time due to the particle losses. Typically coagulation sink increases during a NPF event. In this case, during the growth between two particle sizes, a smaller fraction of the particles formed in the beginning of an event is scavenged by coagulation as compared to particles formed later during the event, assuming that the GR does not change in time. This tends to distort the moment of maximum concentration to earlier time. In total, this method seems to be more probable to over- than underestimate the particle growth rate.

\subsubsection{Mode fitting method}

Second GR calculation method used in this study is the "mode fitting" method (Dal Maso et al., 2005). In this method the particle size distribution is assumed to consist of log-normal modes. First, a multi log-normal distribution function is fitted to the measured particle size distribution. Depending on the case, the multi log-normal fitting procedure assumes size distribution with maximum of three modes (Hussein et al., 2005). The geometric mean diameter of the log-normal nucleation mode, i.e. the median diameter of nucleation mode particles, is obtained as a fitting parameter. The GR of nucleation mode particles is obtained by a leastsquare fitting of a line into the data points of geometric mean diameter as a function of time. As only one line fitting is done for each particle formation event, this method assumes the growth rate to be constant throughout the event. The GR could be obtained as a function of particle size also when applying this mode fitting based method. However, this was not done here since the purpose was to use the same approach which has previously been used in analyses of long data series from SMEAR II station (Dal Maso et al., 2005). In this study, time periods during which the median diameter of the nucleation mode particles was below $20 \mathrm{~nm}$ were selected for the growth rate calculations. Hence, in theory, the size range for the GR calculated with this method is 3-20 nm. In many cases, however, the mode fitting is successful only when a substantial fraction of nucleation mode particles is not below the $3 \mathrm{~nm}$ detection limit, which sets the lower limit for the GR calculation often to $5 \mathrm{~nm}$ or to even larger sizes.

The mode fitting method was applied only on the DMPS data. Typically this method is not used for AIS and BSMA data due to the detection size ranges of these instruments; the log-normal mode can not be distinguished clearly from the small ion mode in the smallest sizes and, on the other hand, as the particles grow larger, information of nucleation mode is partly lost due to the low upper cut of sizes. The latter is the case especially for BSMA. Additionally, if mode fitting method is applied on ion distribution the result may be affected by the size dependence of charged fraction of particles, i.e. the median diameters determined from total and charged particle distributions may not be the same.
As calculated with the mode fitting method, the particle growth rate is the changing rate of the estimated median diameter of the nucleation mode particles. This method is not as sensitive to sudden changes in the size distribution caused by air mass changes as the maximum concentration method. The weakness of the mode fitting method is its inability to estimate the GR of the smallest particles due to the limitations at the distribution fitting stage.

Like the maximum concentration method also the mode fitting method estimates the total average changing rate of the nucleation mode particles size without separation of the contributions of condensational growth and coagulation. However, the effect of coagulation on the evolution of nucleation mode is not always negligible. For instance, a study on particle growth in Atlanta showed that coagulation may account for some tens of percents of the total growth rate (Stolzenburg et al., 2005). In a recent simulation study Leppä et al. (2011) demonstrated how self-coagulation of nucleation mode particles and, especially, coagulational scavenging of the nucleation mode particles by background particles, increase the changing rate of the average diameter of the nucleation mode particles significantly in the situation with high nucleation mode number concentration and high coagulation sink.

Based on the results by Leppä et al. (2011) and using typical nucleation mode number concentrations observed at the SMEAR II, the changing rate of the average diameter of nucleation mode particles due to self-coagulation can be estimated to be $<0.05 \mathrm{~nm} \mathrm{~h}^{-1},<0.2 \mathrm{~nm} \mathrm{~h}^{-1}$ and $<0.5 \mathrm{~nm} \mathrm{~h}^{-1}$ at the size ranges $1.5-3 \mathrm{~nm}, 3-7 \mathrm{~nm}$ and $7-20 \mathrm{~nm}$, respectively. The corresponding rate due to the coagulational scavenging by the pre-existing particles with the average CS of $0.002 \mathrm{~s}^{-1}$ at SMEAR II is estimated to be of the order of $0.1-1 \mathrm{~nm} \mathrm{~h}^{-1}$, with the largest value in the size range of 3$7 \mathrm{~nm}$, slightly lower values in the size range of $1.5-3 \mathrm{~nm}$ and lowest values in the size range of $7-20 \mathrm{~nm}$. It is worth noting that the CS values at SMEAR II occasionally reach substantially higher values during the particle formation events in which cases, based on the result by Leppä et al. (2011), the changing rate of the mode average diameter due to coagulational scavenging could be even several nanometers per hour for the $<7 \mathrm{~nm}$ particles. However, there was considerable scattering in their results between different simulations and, as the authors mentioned, not all of the combinations of the parameters in their simulations were atmospherically relevant. Leppä et al. (2011) pointed out that, if the mode fitting method is used to calculate the growth rate, even if the coagulation sink stays constant the effects of both the self-coagulation and the coagulational scavenging should be considered in order to find the condensational growth rate and to estimate the concentration of condensing vapours. Instead, if the coagulation sink stays constant in time during the growth and the maximum concentration method is used, only the effect of self-coagulation needs to be subtracted. At SMEAR II the CS typically increased during a NPF event, 
and the median CS during the growth period of $1.5-3 \mathrm{~nm}$ particles was $26 \%$ lower than during the growth period of 7-20 nm particles.

In the analysis of this study, primarily the GRs estimated with the maximum concentration method were used and the mode fitting method was employed only to compare these two commonly used GR calculation methods.

\section{Results}

The diameter growth rates of nucleation mode particles were determined for the years 2003-2009 from the particle size distributions measured with DMPS, BSMA and AIS (only until June 2007) with the maximum concentration method. The number of analysed growth periods is presented in Table 2, separated according to the particle size range, instrument and electric charge polarity of the particles.

To obtain a single representative GR value for each event and each size range, the mean of the GR values determined for all three instruments and both polarities for each NPF event was calculated. These event-wise mean GRs obtained using the maximum concentration method are used for studying variations in GR between seasons, years and particle sizes (Sect. 3.1) and for the comparison with the ambient data (Sect. 3.3). The GRs obtained from different instruments are used in the Sect. 3.2 for the uncertainty estimation. The GRs calculated with the mode fitting method are used only for the comparison of the two GR calculation methods in the Sect. 3.2.3.

\subsection{Variation in growth rate between seasons, years and particle sizes}

The GRs of particles smaller than $3 \mathrm{~nm}$ were approximately constant within the accuracy of the method throughout the year, whereas the larger particles, especially in the size range $7-20 \mathrm{~nm}$, had typically larger GRs during the summer months (June, July, August) than during the rest of the year (Fig. 2). The GRs in any of the size classes did not have distinctive maxima in the spring and autumn like nucleation event frequency and new particle formation rate do at SMEAR II (Mäkelä et al., 2000; Dal Maso et al., 2005). This suggests that the processes and/or vapours limiting particle formation rates are different from those limiting the growth and survival of the formed particles to climatically relevant sizes.

The particle growth rates averaged over the whole measurement period increased as a function of particle size (Table 3) and the difference in GR between the size ranges is highlighted during summer months. The expected sizedependence on the mass transfer between the gas phase and aerosol particles can be studied by writing the condensational
Table 2. Number of new particle formation events for which growth rate was calculated separated according to the particle size, the instrument used for size distribution measurement and the electric charge polarity of the particles. The size range $7-20 \mathrm{~nm}$ is out of the detection range of BSMA and the size range $1.5-3 \mathrm{~nm}$ is out of the detection range of DMPS.

\begin{tabular}{lrrr}
\hline & $1.5-3 \mathrm{~nm}$ & $3-7 \mathrm{~nm}$ & $7-20 \mathrm{~nm}$ \\
\hline AIS negative & 116 & 98 & 53 \\
AIS positive & 79 & 95 & 50 \\
BSMA negative & 123 & 137 & - \\
BSMA positive & 65 & 107 & - \\
DMPS & - & 222 & 290 \\
\hline
\end{tabular}

particle growth rate in kinetic regime (particle diameter $\ll 60 \mathrm{~nm}$ ), assuming only one condensing vapour

$\mathrm{GR}=\frac{\alpha_{\mathrm{m}} M v}{4 \rho}\left(c_{\infty}-c_{\mathrm{eq}}\right)$

where $\alpha_{\mathrm{m}}$ is mass accommodation coefficient, $M$ is molecular mass of the vapour, $v$ is the mean thermal velocity of the vapour molecules, $\rho$ is the density of the particle and $c_{\infty}$ is the ambient molar vapour concentration. The equilibrium vapour concentration $c_{\text {eq }}$ over the particle surface can be written as $c_{\mathrm{eq}}=p_{\mathrm{eq}} /(T \cdot R)$, where $T$ is temperature and $R$ is gas constant. The equilibrium vapour pressure at particle surface $p_{\text {eq }}$ is a product of saturation vapour pressure, term depending on particle size and describing the Kelvin effect for curved surface and activity for a multicomponent particle. Therefore, theoretically the growth rate in the kinetic regime depends on particle size only through the equilibrium vapour pressure, if constant mass accommodation coefficient and particle composition is assumed. At least part of the observed increase of the GR with the size of the particles could thus be a result of different vapours condensing on the different size particles due to the decrease of Kelvin effect as a function of particle size (Kulmala et al., 2004b, c). However, it is not possible to overrule the possibility of the change in the GR being due to time- rather than actual size-dependence of the GRs, as the growth typically starts around noon and continues towards the night. The smallest diameters thus represent the time around noon, whereas the larger size are typically reached later in the day (Kulmala et al., 1998).

The seasonal variations in GR had the same pattern each year (Fig. 3) and the seasonal medians of GR did vary somewhat from year to year. Summertime median GR of $7-20 \mathrm{~nm}$ particles was higher than on average in 2006 when the median temperature and UVB radiation intensity were also higher than in the other years. In summer 2006 there were also more NPF events than on an average summer. Yet, the observed GRs in the summer 2006 are within the variations of the GR during the other summers. Figure 3 also shows gradual increase in the winter time median GRs of the 


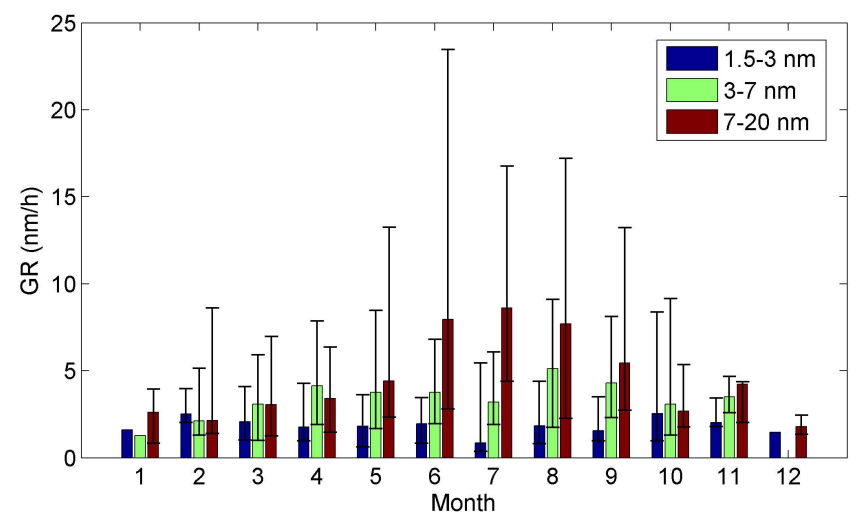

Fig. 2. Monthly median growth rates of particles in the size ranges $1.5-3 \mathrm{~nm}, 3-7 \mathrm{~nm}$ and $7-20 \mathrm{~nm}$ during the years $2003-2009$. The whiskers represent the 10th and 90th percentiles.

larger than $3 \mathrm{~nm}$ particles over the measurement period, and over the years from 2003 to 2008 there was also increase in the winter median temperatures. It should be borne in mind, however, that the number of analysed NPF events was very low during the winters (1-5 events per year) - which of course affects the reliability of this result. Taking into account the variance of the GR values within one year and season, the average GRs did not have particularly distinctive differences between the years. The long data set used in this study shows the same kind of variation in GR between seasons and particle size ranges as Hirsikko et al. (2005) found for a data set covering one year.

\subsection{Uncertainty of the growth rates and comparison of the data from the different instruments}

\subsubsection{Comparison of the instruments}

The uncertainty of particle growth rates obtained from atmospheric measurements with the maximum concentration method was estimated by calculating the standard deviation of the growth rates obtained from the different instruments for each event. Here the two polarities were counted as separate instruments in the case of ion spectrometers. Relative uncertainty of GR resulting from the different measurement techniques was then taken to be the standard deviation of GR between the instruments divided by the mean of GR from the different instruments. Medians over the 81 months measurement period of the event-wise averaged GRs were $1.9 \mathrm{~nm} \mathrm{~h}^{-1}, 3.8 \mathrm{~nm} \mathrm{~h}^{-1}$, and $4.3 \mathrm{~nm} \mathrm{~h}^{-1}$ for 1.5 $3 \mathrm{~nm}, 3-7 \mathrm{~nm}$ and $7-20 \mathrm{~nm}$ particles, respectively (Table 3 ). The corresponding medians of relative uncertainties resulting from the different measurement techniques were $25 \%$, $19 \%$, and $8 \%$. Therefore it can be concluded that the GR values obtained using size distributions measured with different instruments agree reasonably well on average. The relative uncertainty is largest for the smallest particles and the agreement between the GR values obtained from different instruments gets better as the particles grow larger.

The potential systematic differences between the instruments were investigated by considering the fractional relationship between GR obtained from pairs of the instruments, i.e. dividing the GR obtained from one instrument by GR obtained from another instrument for the same size range. For the 1.5-3 nm particles, the GR calculated from the AIS data was on average $47 \%$ and $24 \%$ larger than the GR calculated from the BSMA data when considering positive and negative polarity, respectively. This suggests that there is tendency for the AIS data to result in somewhat higher GRs than the BSMA data for sub-3 $\mathrm{nm}$ particles. Similar difference between GRs obtained from AIS and BSMA was observed in recent calibrations by Gagné et al. (2011) using instruments with precisely determined flow rates. For the larger particles there was no significant systematic difference between the instruments (Fig. 4).

In the light of the variation of the growth rates obtained from the data measured with the different instruments, the differences in median growth rates between the three size ranges during summer (Fig. 3) are significant, and cannot be explained by instrumental variation. The difference is not explained by the effect of coagulational losses in the nucleation mode either. First, as discussed above, the results by Leppä et al. (2011) indicate that at conditions typical in Hyytiälä the intra-modal coagulation of nucleation mode particles has only a minor effect on particle growth. The inter-modal coagulation, on the other hand, would produce an opposite sizedependence than observed. It can therefore be concluded that the size-dependence on the growth most likely results from differences in condensational fluxes to particles of different sizes.

\subsubsection{Effect of electrical charge on the particle growth rate}

In the size range of $1.5-3 \mathrm{~nm}$ the growth rates calculated from size distributions of negatively charged particles $\left(\mathrm{GR}_{\text {neg }}\right)$ were on average somewhat lower than those calculated from size distributions of positively charged particles $\left(\mathrm{GR}_{\mathrm{pos}}\right)$ in the cases of both BSMA and AIS (Fig. 5). The median of $\mathrm{GR}_{\text {neg }}$ divided by $\mathrm{GR}_{\text {pos }}$ was 0.85 for BSMA data and 0.81 for AIS data for the smallest size range. Due to the continuous charging and neutralization of particles in the atmosphere the difference between $\mathrm{GR}_{\text {neg }}$ and $\mathrm{GR}_{\text {pos }}$ is more likely connected to the charging state of aerosol particle population and probably does not suggest that particles with positive charging would grow faster than those with negative charging. Rather, during the NPF events the small negative particles are often seen to appear before the positive ones at the SMEAR II, indicating that negative charging is possibly favoured over positive charging in the nucleation (Laakso et al., 2007a, b). This shifts the peak of the time series of concentration of negative particles around $1.5 \mathrm{~nm}$ to earlier time 

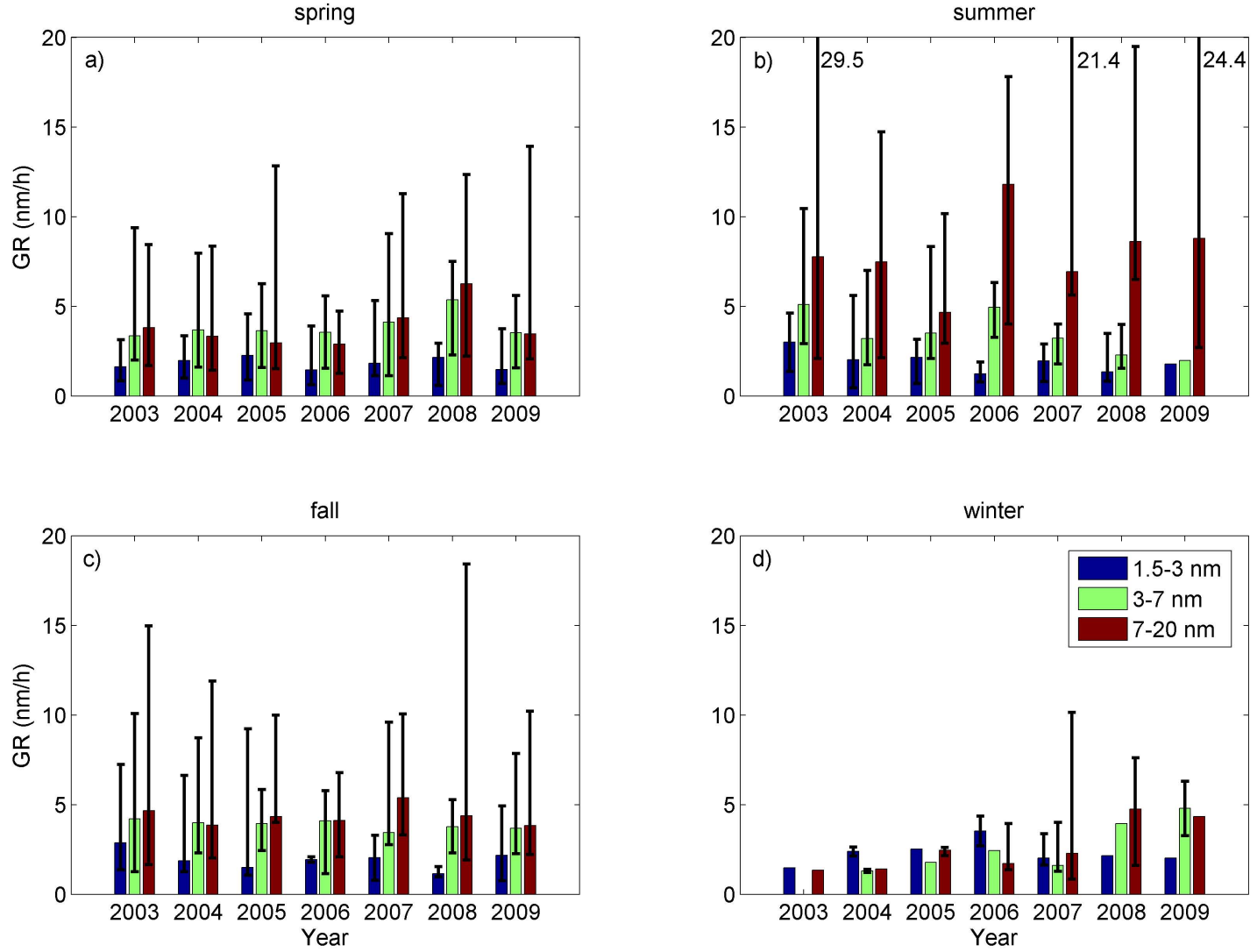

Fig. 3. Median growth rates during (a) spring (March, April, May), (b) summer (June, July, August), (c) fall (September, October, November) and (d) winter (January, February, December) in years 2003-2009 for the three size ranges $1.5-3 \mathrm{~nm}, 3-7 \mathrm{~nm}$ and 7-20 nm. The whiskers represent the 10th and 90 th percentiles.

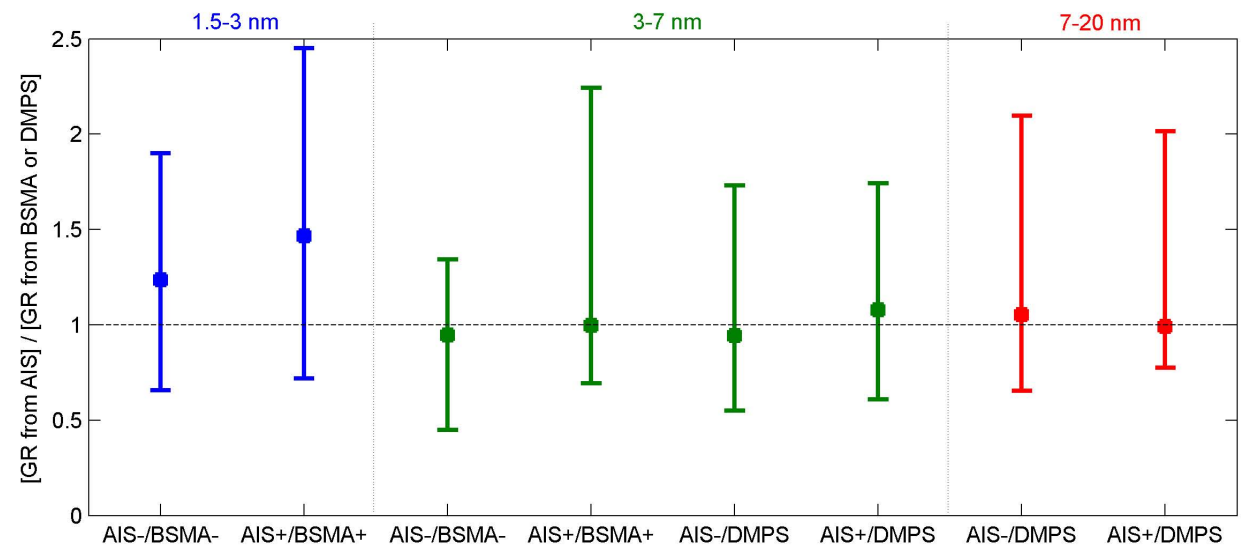

Fig. 4. Ratios of GR values determined from measurements with different instruments for three size ranges. The squares represent the median value of the ratios for the size ranges (the growth rate obtained from AIS divided by the growth rate obtained from BSMA or DMPS). The whiskers represent the 10th and 90th percentiles. Size ranges are marked above the figure. 
Table 3. The medians over the 81 month long measurement period of the particle growth rates averaged from those obtained from the three instruments (DMPS, BSMA and AIS), the medians of the standard deviations between the growth rates obtained from different instruments and the medians and 10th and 90th percentiles of the relative uncertainty of the growth rate values.

\begin{tabular}{llllll}
\hline Size range & $\begin{array}{l}\text { Median of } \\
\text { averaged GRs }\end{array}$ & $\begin{array}{l}\text { Median of } \\
\text { standard deviations } \\
\text { of GRs from the } \\
\text { different instruments }\end{array}$ & $\begin{array}{l}\text { Median of } \\
\text { relative } \\
\text { uncertainty }\end{array}$ & $\begin{array}{l}\text { 10th percentile } \\
\text { of relative } \\
\text { uncertainty }\end{array}$ & $\begin{array}{l}\text { 90th percentile } \\
\text { of relative } \\
\text { uncertainty }\end{array}$ \\
\hline $1.5-3 \mathrm{~nm}$ & $1.9 \mathrm{~nm} \mathrm{~h}^{-1}$ & $0.5 \mathrm{~nm} \mathrm{~h}^{-1}$ & $25 \%$ & $12 \%$ & $53 \%$ \\
$3-7 \mathrm{~nm}$ & $3.8 \mathrm{~nm} \mathrm{~h}^{-1}$ & $0.6 \mathrm{~nm} \mathrm{~h}^{-1}$ & $19 \%$ & $5 \%$ & $45 \%$ \\
$7-20 \mathrm{~nm}$ & $4.3 \mathrm{~nm} \mathrm{~h}^{-1}$ & $0.3 \mathrm{~nm} \mathrm{~h}^{-1}$ & $8 \%$ & $1 \%$ & $34 \%$ \\
\hline
\end{tabular}

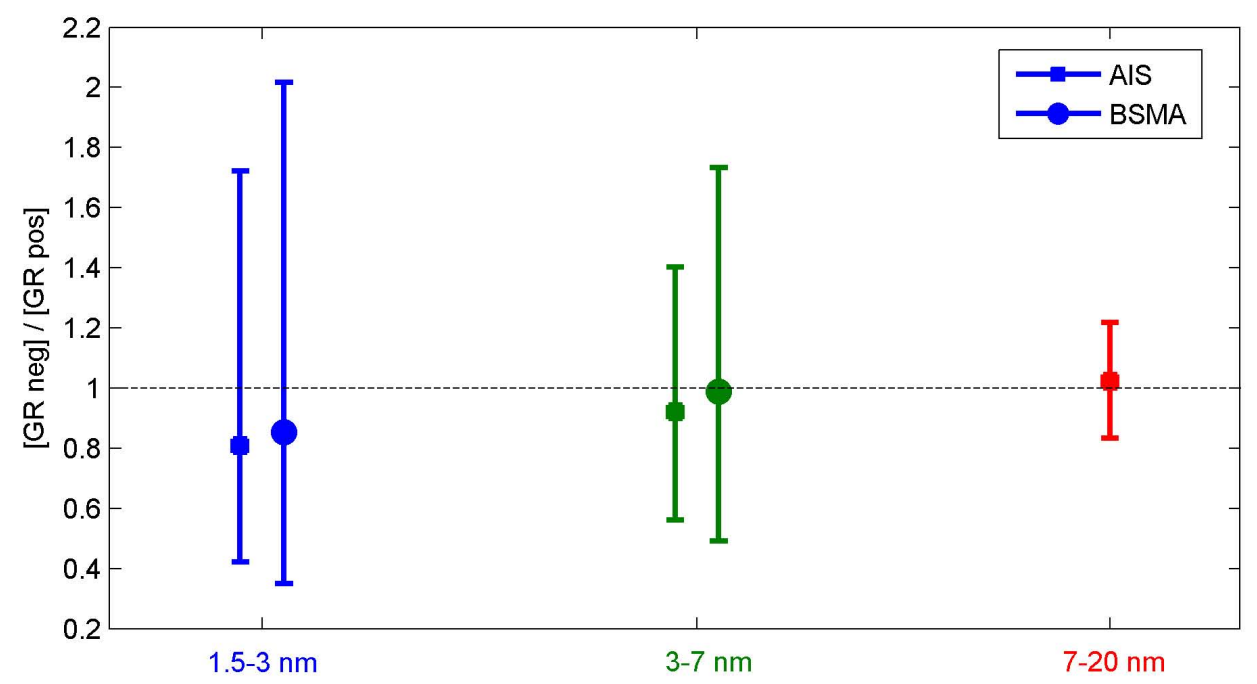

Fig. 5. Ratios of particle growth rates estimated from measurements of positively and negatively charged particles. Results from the AIS and BSMA data are shown separately. The squares and circles represent the median value of the ratio of the growth rates for the size ranges (the growth rate obtained from the size distribution of negative particles divided by the growth rate obtained from the size distribution of positive particles). The whiskers represent the 10th and 90th percentiles.

than the peak in the concentration of positive particles of the same size. If this difference between the electric charge polarities is evened out by charging and neutralization of the particles as they grow, it would lead to $\mathrm{GR}_{\text {pos }}$ being larger than $\mathrm{GR}_{\text {neg }}$ consistent with our observations. The measurements at SMEAR II during QUEST campaign (21 March10 April 2003) showed that the charging state of nanosized aerosol particles can differ from the steady state up to about sizes 5-6nm during NPF events (Hõrrak et al., 2004a, b). Also a study by Gagné et al. (2008) based on one year of data presented similar results.

\subsubsection{Comparison of the GR calculation methods}

For the comparison of the two growth rate calculation methods we used the DMPS data from the years 2003-2009, for which both methods could be applied.
The GR values obtained with the maximum concentration method were typically larger than the values determined with the mode fitting method (Fig. 6a). This was the case for 70 events out of 99 . The median of the difference between the GRs calculated with the two methods was $1.1 \mathrm{~nm} \mathrm{~h}^{-1}$. Relative uncertainty related to the differences in the GR calculation methods was estimated similarly to the relative uncertainty related to different instruments, i.e. by dividing the standard deviation between the GRs calculated with the different methods for an event by the mean of these GRs. The median of the relative uncertainty resulting from the different GR calculation methods was $16 \%$. Correlation coefficient between the GRs estimated with the two methods was 0.72 with p-value less than $10^{-15}$. The result suggests that, for the larger than $3 \mathrm{~nm}$ particles, the choice of GR calculation method causes similar uncertainty in the GR values as the uncertainty due to different instruments. Both methods, however, capture the trends in the GR values in a similar manner. 
Two groups (denoted as Group 1 and Group 2 from here on) with specific characteristics could be distinguished among the events (Fig. 6). Group 1 ("Large initial size") consists of events where the GR applying the mode fitting method was calculated starting from clearly larger sizes than $3 \mathrm{~nm}$, since the median diameter of the nucleation mode was found from these larger sizes at the beginning of the event (Fig. 6b). For the group 1 events the maximum concentration method starting from $3 \mathrm{~nm}$ size typically gave slightly higher growth rates than the mode fitting method (Fig. 6a). One situation which could result in group 1 type of behaviour is that if nucleation started at a higher altitude and the air mixed into sampling height while particles were growing. In this kind of situation the mode fitting method might be more suitable way to calculate GR as the geometric mean diameter is not affected by the air mass changes. Group 2 ("Small initial size") consists of events where the mode fitting was successful also when the median diameter of the nucleation mode was closer to the $3 \mathrm{~nm}$ detection limit and the median diameter of the mode was detected at each size class of the particles before the concentration of that size particles reached its maximum (Fig. 6c). In these cases the growth rates obtained with the two methods agreed better than in the case of group 1 events. For group 2 events it was typical for nucleation mode particle number concentration to increase during the time from which growth rate was calculated. This was also the case for some group 1 events, although for group 1 events it was also typical for the number concentration to first increase and then stay constant or decrease during the growth rate calculation time period. Overall, when nucleation is still continuing, the representative diameter for nucleation mode particles is often found from the larger sizes with the mode fitting method compared to the maximum concentration method. Also, the start time of $3 \mathrm{~nm}$ particle growth determined by the two methods can be different despite of the similar slopes of the GR regression lines (see Fig. 6c).

As a summary, it can be concluded that although there are differences in the GR values calculated with the two methods, the values were of the same order and the seasonal variations in the GRs is the same (see above and Hirsikko et al., 2005; Dal Maso et al., 2005).

\subsection{Ambient conditions favouring the growth}

The seasonal variation of the growth rates of nucleation mode particles were observed to differ in the three size ranges: the $1.5-3 \mathrm{~nm}$ growth showed practically no seasonal dependence, while the 3-7 nm and 7-20 nm GRs showed a very pronounced maximum in the summer. Typically a NPF event started in the morning around 09:00 LT and the mean diameter of the nucleation mode had reached $20 \mathrm{~nm}$ around 15:0017:00 LT. At summertime the temperature at SMEAR II typically rises during most of this time having its daily maximum in the afternoon. Therefore, and due to the exponential dependence of monoterpene emissions with temperature
(Guenther et al., 1993), the daily pattern of the particle growth rates - if the size-dependence is interpreted that way - as well as the seasonal pattern, is in line with the oxidation products of biogenic VOCs being key compounds in particle growth.

A connection between the growth rate and temperature was seen when comparing growth rates to ambient temperature during the growth. The GR of the $7-20 \mathrm{~nm}$ nucleation mode particles had an exponential dependence on the ambient temperature with the linear correlation coefficient $(R)$ of 0.46 between temperature and logarithm of GR (Fig. 7a). This is similar to the temperature dependence of ambient monoterpene concentration (Lappalainen et al., 2009). The connection to temperature was less obvious for the GR in the size range $3-7 \mathrm{~nm}$ (Fig. $7 \mathrm{~b}$ ) and for the smallest particles $(1.5-3 \mathrm{~nm})$ there was no correlation between the GR and temperature (Fig. 7c). These observations are naturally in line with the observed seasonal variation depicted in Fig. 2.

Due to the connection of UVB radiation to oxidant concentrations and the oxidation of VOCs (and $\mathrm{SO}_{2}$ ), a linear correlation between UVB radiation intensity and particle growth rates could be expected (Eq. 4). Despite this, still a moderate correlation with $R=0.35$, was found for the 7$20 \mathrm{~nm}$ particles, and a stronger correlation with $R=0.41$ was found between $\ln (\mathrm{GR})$ and UVB radiation intensity (Fig. 8a). This could be explained by a strong coupling of UVB radiation intensity with temperature $(R=0.75$ for the event time mean values) which suggests that at SMEAR II the concentration of VOCs is at least as important limiting factor for nucleation mode growth as compared with the concentration of oxidizing molecules $\mathrm{OH}$ and $\mathrm{O}_{3}$ (see Fig. 1). Growth rates of particles smaller than $7 \mathrm{~nm}$ did not show a clear connection with UVB radiation intensity (Fig. $8 \mathrm{~b}$ and c).

As suggested by the correlation of GR with exponent of temperature, the GR of 7-20 nm particles correlated strongly positively with the event time median monoterpene concentration with correlation coefficient of 0.76 (Fig. 9). However, if the one data point with highest GR in Fig. 9a is excluded from the analysis the correlation coefficient is only 0.33 (with p-value 0.2 ) - reflecting the challenge of collecting large enough data sets for significant statistics in the real ambient atmosphere where concentrations and conditions are highly fluctuating. Growth rates of the smaller particles did not show any correlation with monoterpene concentrations. The amount of monoterpene data was limited and therefore GR was compared also with temperature-based modelled monoterpene concentration (Lappalainen et al., 2009) using event time median temperature. The growth rates in the size range $7-20 \mathrm{~nm}$ correlated less strongly with the modelled monoterpene concentration compared to measured concentration. Also for the growth rates of the 3-7 nm there was a weak positive correlation with the modelled monoterpene concentration.

Monoterpenes are not expected to condense on the particles due to their relatively high saturation vapour pressures 

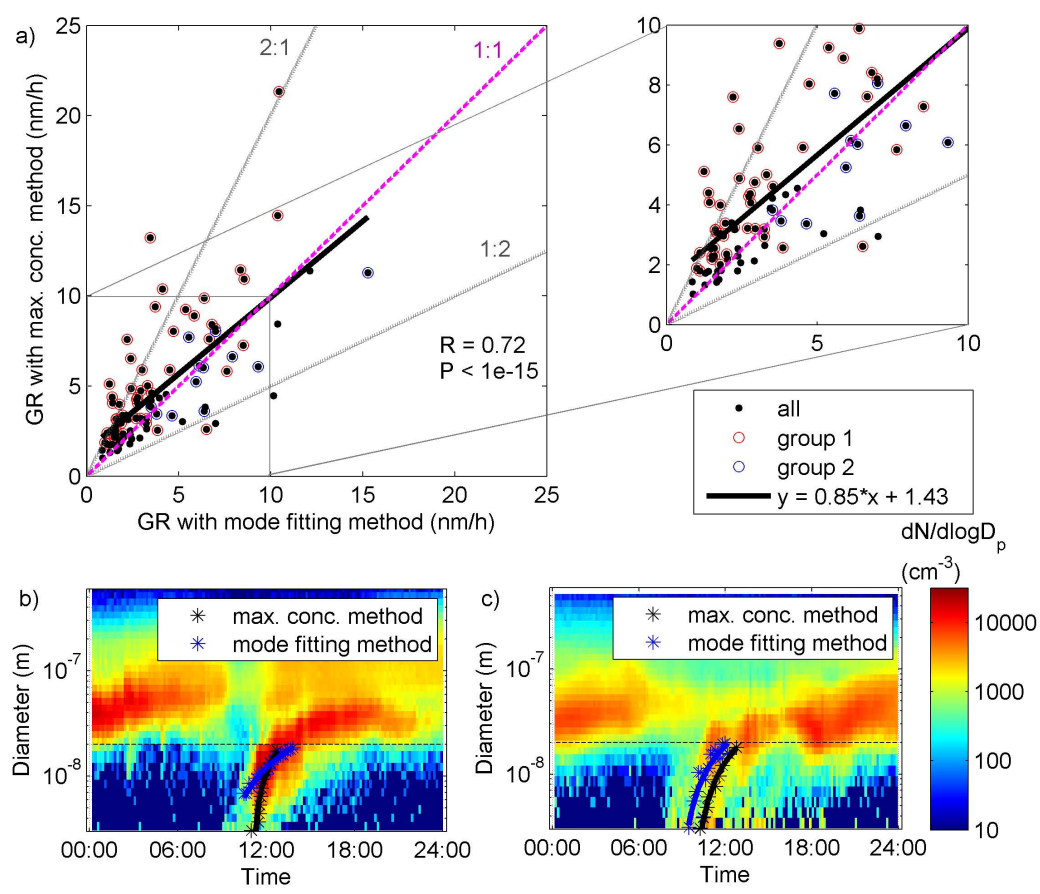

Fig. 6. (a) Comparison of the growth rates calculated applying the maximum concentration method (y-axis) to growth rate calculated with mode fitting method (x-axis) from DMPS data for the size range of 3-20 nm. Also shown are the straight line fitted to the data and the correlation coefficient and p-value between the growth rates calculated with the two methods. The dashed line is the 1:1 line and the dotted lines represent the factor of two difference in the growth rates. Examples of the (b) Group 1 (large initial size in mode fitting method) and (c) Group 2 (small initial size in mode fitting method) events with the points showing the representative sizes of the nucleation mode found with the two GR calculation methods as a function of time and the lines corresponding to the fitted straight lines in linear diameter scale. The size distributions are measured with DMPS and the color indicates the concentration.

- it is rather their oxidation products that take part in the growth process (see Fig. 1). Measurement-based calculated oxidation rates of monoterpenes with $\mathrm{O}_{3}$ correlated positively with the GR of 7-20 nm particles with $R=0.80$. However, also for the oxidation rate with $\mathrm{O}_{3}$ the correlation is considerably weaker ( $R=0.26$ with p-value 0.4$)$ if the data point with the highest GR value in Fig. 9c is excluded. The comparison of GR with oxidation rate of monoterpenes with $\mathrm{OH}$ and the sum of the oxidation rates did not show a clear connection. Like in the case of the concentration of monoterpenes, also in the case of oxidation rates of monoterpenes the statistical significance of the correlations is low due to the scarcity of the data. Also, availability of measured $\mathrm{OH}$ concentration data limited the oxidation rate data for only two months in spring 2007. Therefore, the GR was compared also to modelled oxidation rates of monoterpenes. These modelled oxidation rates had weak positive correlation with GR of 7-20 nm particles with correlation coefficient smaller than between GR and modelled concentration of monoterpenes. For the GR of the smaller particles there was no notable correlation with the modelled oxidation rates.

If condensation of vapours to the pre-existing particles was limiting the growth of the nucleation mode particles, a positive correlation between GR and the inverse of condensation sink $\left(\mathrm{CS}^{-1}\right)$ would be expected (see Fig. 1). On the contrary, according to this dataset, there is a weak negative correlation between GR of 7-20 nm particles and $\mathrm{CS}^{-1}$. The data points with low $\mathrm{CS}^{-1}$ and high GR were those with also the highest temperature and, therefore, the negative correlation between GR and $\mathrm{CS}^{-1}$ likely originates from the positive correlation between CS and temperature. The growth rates of sub- $7 \mathrm{~nm}$ particles did not have correlation with $\mathrm{CS}^{-1}$.

Formation rate of particles has been seen to be connected with sulphuric acid concentration. Yet, the growth rates of particles at each of the size ranges had only a weak positive correlation with the $\mathrm{H}_{2} \mathrm{SO}_{4}$ concentration proxy (Table 4). Also, the GRs measured in this study are too large to be explained with sulphuric acid as the major condensing vapour (Nieminen et al., 2010) even for the smallest particles. In typical conditions at SMEAR II sulphuric acid could cause growth slower than $1 \mathrm{~nm} \mathrm{~h}^{-1}$ (Boy et al., 2005) whereas the growth rates obtained in this study were mostly larger than this in all three size ranges.

The GR in the three size ranges were compared also to other meteorological data and gas concentrations. In general, the GR of $1.5-3 \mathrm{~nm}$ particles did not correlate with any of these variables. This might suggest that the actual growth rate of these small particles does not correlate with 

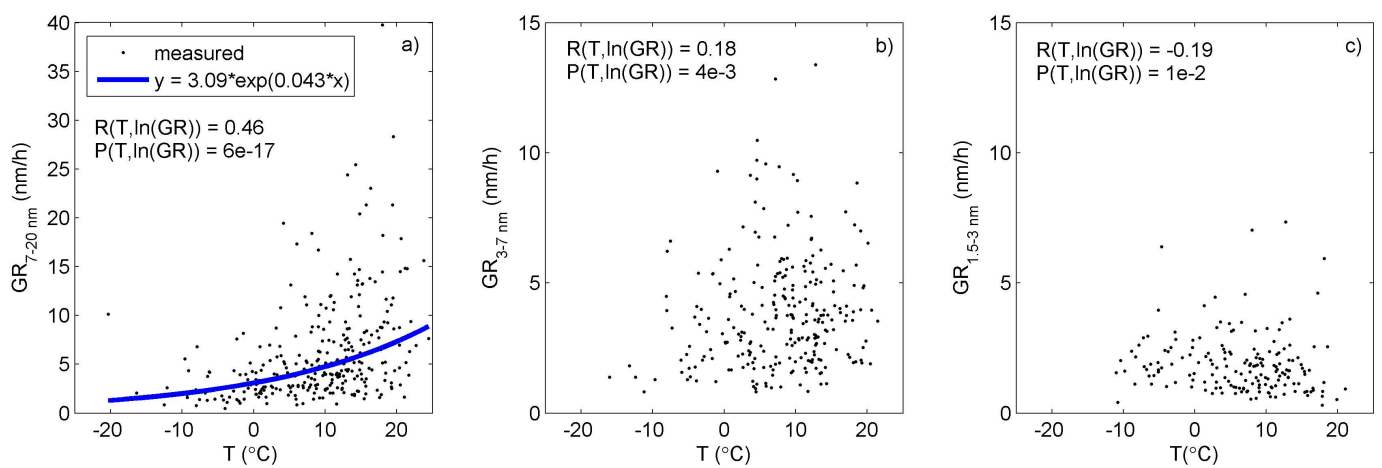

Fig. 7. Growth rate (GR) of particles in the size ranges (a) 7-20 nm, (b) $3-7 \mathrm{~nm}$ and (c) $1.5-3 \mathrm{~nm}$ as a function of temperature (T) and the correlation coefficient $(R)$ and p-value between temperature and natural logarithm of GR. For size range 7-20 nm also shown is the fitted line $\mathrm{GR}=a_{1} \cdot \exp \left(b_{1} \cdot T\right)$.
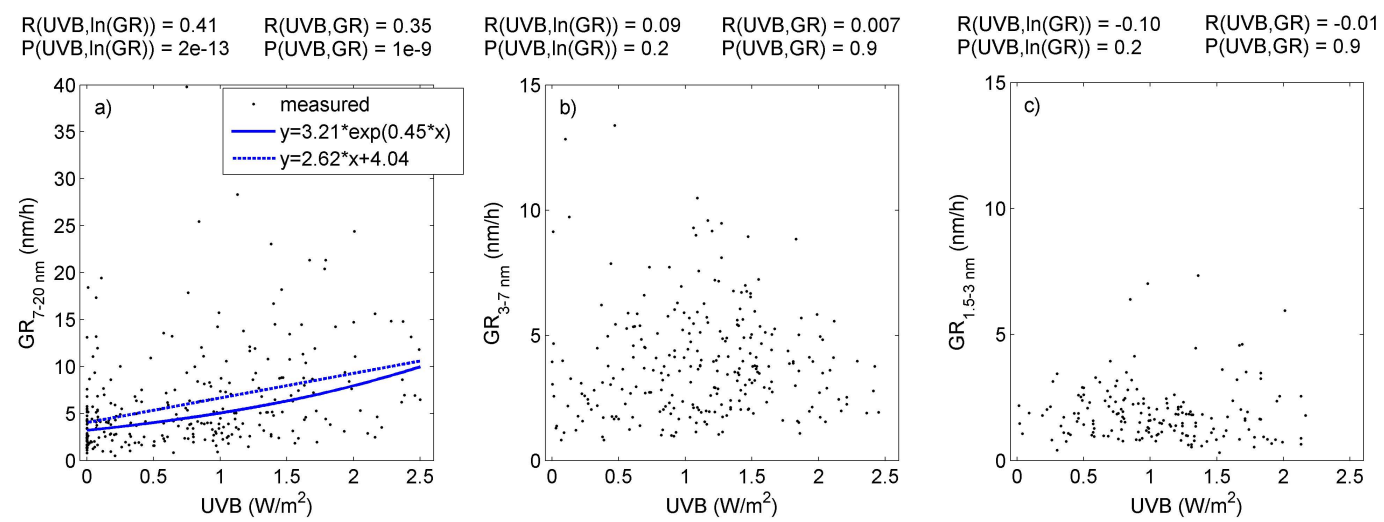

Fig. 8. Growth rate (GR) of particles in the size ranges (a) 7-20 nm, (b) 3-7 nm and (c) $1.5-3 \mathrm{~nm}$ as a function of UVB radiation intensity (UVB) and the correlation coefficients $(R)$ and p-values between UVB and GR and natural logarithm of GR. For size range 7-20 nm also shown are the fitted lines $\mathrm{GR}=a_{2} \cdot \exp \left(b_{2} \cdot \mathrm{UVB}\right)$ and $\mathrm{GR}=b_{3} \cdot \mathrm{UVB}+a_{3}$.
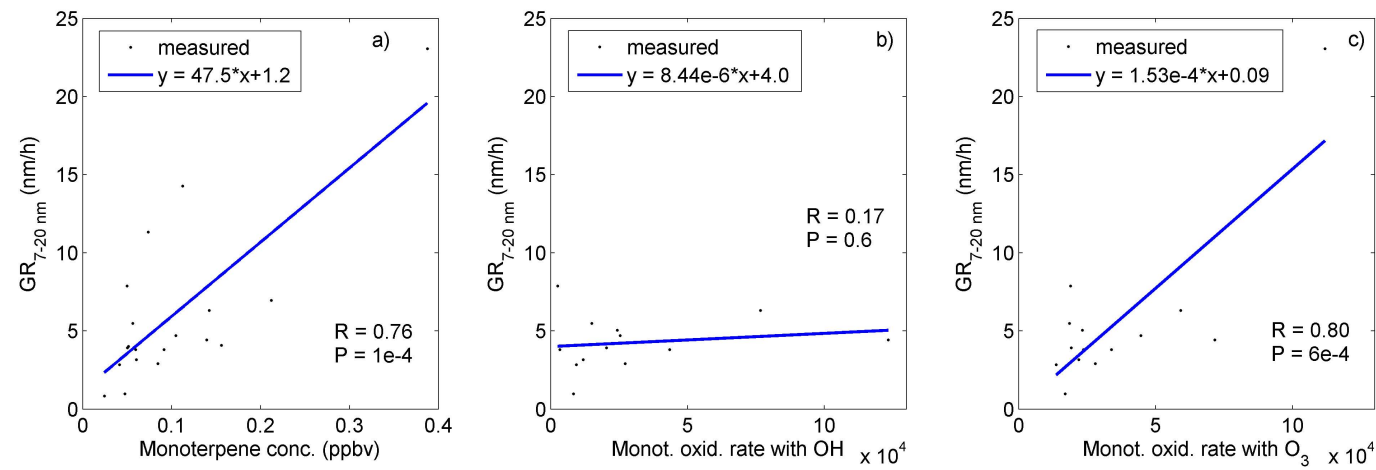

Fig. 9. Growth rate (GR) of particles in the size ranges $7-20 \mathrm{~nm}$ as a function of event time median (a) concentration of monoterpenes, measurement based calculated oxidation rates of monoterpenes with (b) $\mathrm{OH}$ and (c) $\mathrm{O}_{3}$. Also shown are the linear fits and the correlation coefficients. 
Table 4. Correlation coefficients $R$ (and p-values) between growth rates of the particles in the size ranges $1.5-3 \mathrm{~nm}, 3-7 \mathrm{~nm}$ and $7-20 \mathrm{~nm}$ and the meteorological variables, gas concentrations and condensation sink. For monoterpene concentration and oxidation rates of monoterpenes, as well as for modeled monoterpene concentration and modelled oxidation rates of monoterpenes event time (time period of growth from $1.5 \mathrm{~nm}$ to $20 \mathrm{~nm}$ ) median values were used. Otherwise, median values from the growth time in each size range were used. Correlations with $R>0.40$ are indicated in bold.

\begin{tabular}{lrrr}
\hline & GR 1.5-3 nm & GR 3-7 nm & GR 7-20 nm \\
\hline$T$ & $R=-0.11(p=0.2)$ & $0.12(0.05)$ & $0.39\left(8 \times 10^{-12}\right)$ \\
$T$ vs. ln(GR) & $-0.19(0.01)$ & $0.18\left(4 \times 10^{-3}\right)$ & $\mathbf{0 . 4 6}\left(\mathbf{6} \times \mathbf{1 0}^{-17}\right)$ \\
UVB & $-0.01(0.9)$ & $0.007(0.9)$ & $0.35\left(1 \times 10^{-9}\right)$ \\
UVB vs. ln(GR) & $-0.10(0.2)$ & $0.09(0.2)$ & $\mathbf{0 . 4 1}\left(\mathbf{2} \times \mathbf{1 0}^{-13}\right)$ \\
Conc. of monoterpenes & $-0.08(0.7)$ & $-0.04(0.9)$ & $\mathbf{0 . 7 6}\left(\mathbf{1} \times \mathbf{1 0}^{-4}\right)$ \\
Modelled conc. of monoterpenes & $-0.13(0.1)$ & $0.19(0.05)$ & $0.35\left(7 \times 10^{-5}\right)$ \\
Monot. oxid. rate with OH & $-0.14(0.7)$ & $-0.13(0.7)$ & $0.17(0.6)$ \\
Monot. oxid. rate with $\mathrm{O}_{3}$ & $0.01(1.0)$ & $0.13(0.7)$ & $\mathbf{0 . 8 0}\left(\mathbf{6} \times \mathbf{1 0}^{-4}\right)$ \\
Sum of monot. oxid. rates & $-0.04(0.9)$ & $-0.4(0.9)$ & $0.20(0.5)$ \\
Modelled monot. oxid. rate with $\mathrm{OH}$ & $-0.11(0.2)$ & $0.14(0.1)$ & $0.31\left(6 \times 10^{-4}\right)$ \\
Modelled monot. oxid. rate with $\mathrm{O}_{3}$ & $-0.13(0.1)$ & $0.11(0.3)$ & $0.22(0.01)$ \\
Sum of modelled monot. oxid. rates & $-0.12(0.2)$ & $0.12(0.2)$ & $0.28\left(2 \times 10^{-3}\right)$ \\
CS $^{-1}$ & $-0.05(0.5)$ & $-0.08(0.2)$ & $-0.21\left(4 \times 10^{-4}\right)$ \\
$\mathrm{O}_{3}$ & $0.01(0.9)$ & $-0.07(0.3)$ & $-0.10(0.10)$ \\
$\mathrm{H}_{2} \mathrm{SO}_{4}$ conc. proxy & $0.20(0.02)$ & $0.12(0.06)$ & $0.23\left(2 \times 10^{-4}\right)$ \\
\hline
\end{tabular}

the compared variable or that the process connecting the two is not linear. This apparent non-correlation might also be a consequence of the uncertainty in the calculated GR at the smallest size range. Water vapour concentration correlated positively with GR of 3-7 nm (correlation coef. 0.22) and $7-20 \mathrm{~nm}$ (correlation coefficient 0.48 ) particles, presumably due to the strong connection between temperature and water vapour concentration. However, relative humidity did not correlate with GR. Wind speed, ambient pressure or concentrations of inorganic trace gases $\mathrm{NO}, \mathrm{NO}_{\mathrm{x}}, \mathrm{CO}, \mathrm{CO}_{2}$ and $\mathrm{SO}_{2}$ did not have notable correlations with particle growth rates.

\section{Discussion}

We observed that the GR values consistently increased as a function of particle size. There are at least two likely reasons for this increase. First, the increase of the equilibrium vapour pressure with decreasing particle size could hinder significantly the mass flux of condensing vapours to the smallest particles or even inhibit some of the vapours able to condense on the larger particles from condensing on the smallest particles. Second, the growth of larger particles is occurring later during the day compared to the growth of the smaller particles. Therefore, the ambient vapour concentrations may be different during the growth periods of particles in different size ranges, which would result in change in GR apparently as a function of the particle size. With the method used in this study the size and time dependence in GR can not be separated. In the recent study by Kuang et al. (2011), where a GR calculation method capable for decoupling size and time dependence in GR was developed, both of these dependencies were observed. Kuang et al. (2011) studied growth of 1-5 nm particles in Boulder and in Atlanta, and found that at the size range below $3 \mathrm{~nm}$ GR increased linearly with particle size and, throughout the studied size range, the GR increased as a function of time. The increase of GR as a function of the particle size suggests that the growth of the particles is not due to the same vapour that forms particles through nucleation (McMurry and Wilson, 1982; Kulmala et al., 2004b). This conclusion is supported by the different seasonal variations of GR and NPF event frequency and it agrees with the observations from other sites (e.g. Weber et al., 1997). The increase of GR with particle size is observed also at other sites with both clean and polluted atmospheres (Table 1). However, there are also observations of relatively constant GRs as a function of particle size from at least coastal and high altitude sites, where the lack of increase of the estimated GRs as a function of particle size is speculated to be due to inhomogeneities of condensable vapour source (Manninen et al., 2010). Also a study from Heidelberg, Germany, indicated on average similar growth rates for sub- $3 \mathrm{~nm}$ particles as for larger particles (Fiedler et al., 2005). There the reason was speculated to be either low volatile anthropogenic organic vapours or a point source, which would distract the growth rate estimation at sub- $3 \mathrm{~nm}$ size range.

Growth rates of larger than $3 \mathrm{~nm}$ particles showed a clear seasonal variation with the highest values during summer. The seasonal pattern was similar from year to year and it was especially strong for the $7-20 \mathrm{~nm}$ particles. This observation 
emphasises the role of biogenic organic compounds in growing the freshly formed aerosol particles that has also been observed in previous studies (Dal Maso et al., 2005; Allan et al., 2006; Riipinen et al., 2011). It also suggests that the growth is limited by the concentration of the condensing vapours and not by their saturation vapour pressures - which has a large positive temperature dependence. This supports the results from previous studies that indicate that the saturation vapour concentration of the condensing vapour should be at least two orders of magnitude lower than the ambient vapour concentration to explain the observed GRs of nucleation mode particles at SMEAR II (Kulmala et al., 1998; Riipinen et al., 2011; Pierce et al., 2011). The concentration of the oxidised organic vapours is affected by the concentration of the volatile precursor vapours, their oxidation rate and the vapour sinks. We also observed a clear positive correlation of GR of 7-20 nm particles with the monoterpene concentration and the exponent of ambient temperature. The correlation with most of the oxidation-related parameters was somewhat weaker compared to parameters related to VOC concentrations, and oxidation by $\mathrm{O}_{3}$ seemed to be more important than oxidation by $\mathrm{OH}$ for nucleation mode particle growth. This suggests that the emissions of the BVOCs are at least as important limiting factor for the concentration of condensing vapour as their oxidation. These results could be connected to NPF in general taking place mainly on days with clear sky when the radiation intensity is not limiting the oxidation (Sogacheva et al., 2008). Our results thus suggest that although light intensity and $\mathrm{OH}$-oxidation are important factors controlling nucleation, the growth of the nucleated particles seems to be limited more by the concentrations of the precursor gases and their oxidation by ozone. This is in line with laboratory study by Hao et al. (2011).

Growth rates of $1.5-3 \mathrm{~nm}$ particles did not have seasonal variation and they did not correlate with the ambient parameters. The limiting factor for the growth of these particles is therefore unclear. The equilibrium vapour pressure over the particle surface increases with a decreasing particle size. Thus, it is possible that the effect of increased vapour concentration on the growth rate during summer is damped by the exponential increase of saturation vapour pressure with temperature in the case of the smallest particles. This could explain the observed increase in the average GRs with the size of the particles during summer. On the other hand, coagulation is expected to affect the GR obtained from the particle size distribution more in the case of the smaller particles. Until quantitative estimates on the seasonal variability of the composition of the smallest particles are available, it is difficult to speculate on the exact reasons for the lack of seasonal cycle for the growth of the smallest particles.

Previously, Dal Maso et al. (2005) utilized long term measurements at SMEAR II and showed that the nucleation mode particle growth rates - as determined with the mode-fitting method - at size range 3-25 $\mathrm{nm}$ had seasonal pattern with the highest growth rates during summer. In addition for boreal forest region, similar seasonal pattern in nucleation mode particle growth rates, differentiating from the seasonal pattern of the particle formation frequency, has been observed at a high-elevation site in Hohenpeissenberg, Germany (Birmili et al., 2003). Hirsikko et al. (2005) studied one year of data from SMEAR II and found that the seasonal pattern occurred for 3-7 nm and 7-20 nm particles and that the growth rates of sub- $3 \mathrm{~nm}$ particles were relatively constant throughout the year. In the present study the particle growth rates were studied for the first time as a function of particle size using long term observations. It was found that the seasonal variation in GRs at different size ranges were each year similar to that observed by Hirsikko et al. (2005). We did not find a distinctive interannual variation in the GR values.

The seasonal cycles and the increase in the GR as a function of size cannot be explained by the uncertainty in the results. When using the method of maximum concentration for calculating the GR, the average relative uncertainties of the GRs were estimated to be $25 \%, 19 \%$ and $8 \%$ for the particle size ranges of $1.5-3 \mathrm{~nm}, 3-7 \mathrm{~nm}$ and $7-20 \mathrm{~nm}$, respectively. For the smallest particles, $1.5-3 \mathrm{~nm}$ in diameter, size distribution measured with the AIS resulted on average in higher GRs than size distribution measured with the BSMA, and in the case of both of these instruments the growth rates calculated from the size distribution of positive particles was higher than that calculated using measurements of negative particles. For particles larger than $3 \mathrm{~nm}$ such systematic differences were not observed. For the 3-20 nm size range the maximum concentration method gave typically higher GRs than the mode fitting method and the uncertainty associated with the GR analysis method was similar to the uncertainty associated to different measurement techniques. All in all, we can conclude that an uncertainty of a factor of two is a conservative estimate for the maximum uncertainty in the growth rates determined using the conventional methods and size distribution instrumentation.

Uncertainty estimation for GRs is not often found from the previous studies. However, Boulon et al. (2010) and Manninen et al. (2010) obtained yearly averages of $5.1 \mathrm{~nm} \mathrm{~h}^{-1}$ and $3.7 \mathrm{~nm} \mathrm{~h}^{-1}$, respectively, for sub- $3 \mathrm{~nm}$ particles from the same one year data set measured at high altitude site Jungfraujoch, Switzerland. These two studies used a maximum concentration method but with different modifications: Manninen et al. (2010) used the method described in this paper whereas Boulon et al. (2010) considered the time lag between the maximum concentrations of particles in two size classes. Additionally, Manninen et al. (2010) determined the GR for particle size range of $1.5-3 \mathrm{~nm}$ whereas Boulon et al. (2010) considered size range of $1.3-3 \mathrm{~nm}$. The variation between the GR values obtained in these two studies is likely due to these differences. This difference in GRs is of the same order as the uncertainty found in the present study. 


\section{Conclusions}

In this study the growth of nucleation mode particles during new particle formation events was studied using almost $7 \mathrm{yr}$ of particle size distribution measurements at boreal forest site SMEAR II, Hyytiälä, Finland. The measurements were performed with a DMPS, a BSMA and an AIS, and the data from the years 2003-2009 was analysed. The particle growth rate (GR) was calculated for three size ranges: $1.5-3 \mathrm{~nm}, 3-7 \mathrm{~nm}$ and $7-20 \mathrm{~nm}$ in diameter. The variation in GRs between the seasons, years and particle size ranges was examined, the uncertainty of the calculated GR values was studied, two GR calculation methods were compared, and the connections of GR to ambient conditions were analysed. Here, the main method for calculating the GR from the particle size distributions was based on the time lags between the maxima of the concentrations of different sized particles during an event, and a method based on the time evolution of the median diameter of the nucleation mode particles was utilized for comparison.

A clear dependence on particle size was observed in GR. On average the GR increased with the particle size and this was emphasised during summer. The GR of the smallest particles, $1.5-3 \mathrm{~nm}$ in diameter, did not show seasonal variation, whereas the GRs of larger particles, 3-7 nm and 7-20 nm in diameter, had clear seasonal pattern with highest values during summer. No clear interannual variation was observed. The results indicate that the GR is not connected to nucleation process. A clear dependence of GR on the ambient temperature was observed. Based on the seasonal pattern of the GR of larger than $3 \mathrm{~nm}$ particles and the correlations of GR with the ambient parameters the concentrations of BVOCs seem to be the most important ambient variable connected to the GR.

The comparison of the three instruments showed that the currently used instruments for charged and total particle size distribution measurements give relatively similar results for GR. The median relative uncertainty in GR, estimated based on the results from the three instruments, was for all size ranges $25 \%$ or less. The difference between the GRs of 3$20 \mathrm{~nm}$ particles calculated with the two GR calculation methods was of the same order as the difference between GRs calculated from the size distributions measured with different instruments. The results thus imply that the uncertainty related to the data analysis method is similar to that related to the difference between the instruments.

This study sheds light on the mechanisms limiting the long-term changes in the growth of nucleation mode particles and thus also their contribution to $\mathrm{CCN}$ concentrations: based on our results, the growth seems to be limited by the emissions and concentrations of organic vapours - rather than their saturation vapour pressures. Our results thus suggest that increasing temperature will result in increasing survival probability of nucleated particles - even to the extent that temperature might be a good proxy for the source of
CCNs' from the boreal forest areas in large-scale models. To pin down the exact mechanisms governing the growth of ultrafine particles and aerosol production from the boreal zone, more detailed laboratory and field studies are needed.

Acknowledgements. The financial support by the Academy of Finland Centre of Excellence program (project No. 1118615) and project No. 128731, Maj and Tor Nessling foundation, EUFP7-ATMNUCLE project (ERC Grant Agreement No. 227463), EU-FP7-ATMOGAIN project (ERC Grant Agreement No. 278277) and University of Helsinki funds is gratefully acknowledged. This research was in part supported also by the Estonian Science Foundation through grant 8342. Johannes Leppä is acknowledged for the discussions. We thank K. Iida and two anonymous referees for the comments.

Edited by: W. Birmili

\section{References}

Asmi, E., Kivekäs, N., Kerminen, V.-M., Komppula, M., Hyvärinen, A.-P., Hatakka, J., Viisanen, Y., and Lihavainen, H.: Secondary new particle formation in Northern Finland Pallas site between the years 2000 and 2010, Atmos. Chem. Phys. Discuss., 11, 25709-25750, doi:10.5194/acpd-11-25709-2011, 2011.

Aalto, P., Hämeri, K., Becker, E., Weber, R., Salm, J., Mäkelä, J. M., Hoell, C., O’Dowd, C. D., Karlsson, H., Hansson, H.-C., Väkevä, M., Koponen, I. K., Buzorius, G., and Kulmala, M.: Physical characterization of aerosol particles during nucleation events, Tellus B, 53, 344-358, 2001.

Allan, J. D., Alfarra, M. R., Bower, K. N., Coe, H., Jayne, J. T., Worsnop, D. R., Aalto, P. P., Kulmala, M., Hyötyläinen, T., Cavalli, F., and Laaksonen, A.: Size and composition measurements of background aerosol and new particle growth in a Finnish forest during QUEST 2 using an Aerodyne Aerosol Mass Spectrometer, Atmos. Chem. Phys., 6, 315-327, doi:10.5194/acp-6-315-2006, 2006.

Barsanti, K. C., McMurry, P. H., and Smith, J. N.: The potential contribution of organic salts to new particle growth, Atmos. Chem. Phys., 9, 2949-2957, doi:10.5194/acp-9-2949-2009, 2009.

Birmili, W., Berresheim, H., Plass-Dülmer, C., Elste, T., Gilge, S., Wiedensohler, A., and Uhrner, U.: The Hohenpeissenberg aerosol formation experiment (HAFEX): a longterm study including size-resolved aerosol, $\mathrm{H}_{2} \mathrm{SO}_{4}, \mathrm{OH}$, and monoterpenes measurements, Atmos. Chem. Phys., 3, 361-376, doi:10.5194/acp-3-361-2003, 2003.

Boulon, J., Sellegri, K., Venzac, H., Picard, D., Weingartner, E., Wehrle, G., Collaud Coen, M., Bütikofer, R., Flückiger, E., Baltensperger, U., and Laj, P.: New particle formation and ultrafine charged aerosol climatology at a high altitude site in the Alps (Jungfraujoch, 3580 m a.s.l., Switzerland), Atmos. Chem. Phys., 10, 9333-9349, doi:10.5194/acp-10-9333-2010, 2010.

Boy, M., Kulmala, M., Ruuskanen, T. M., Pihlatie, M., Reissell, A., Aalto, P. P., Keronen, P., Dal Maso, M., Hellen, H., Hakola, H., Jansson, R., Hanke, M., and Arnold, F.: Sulphuric acid closure and contribution to nucleation mode particle growth, Atmos. Chem. Phys., 5, 863-878, doi:10.5194/acp-5-863-2005, 2005. 
Boy, M., Karl, T., Turnipseed, A., Mauldin, R. L., Kosciuch, E., Greenberg, J., Rathbone, J., Smith, J., Held, A., Barsanti, K., Wehner, B., Bauer, S., Wiedensohler, A., Bonn, B., Kulmala, M., and Guenther, A.: New particle formation in the Front Range of the Colorado Rocky Mountains, Atmos. Chem. Phys., 8, 15771590, doi:10.5194/acp-8-1577-2008, 2008.

Cheung, H. C., Morawska, L., and Ristovski, Z. D.: Observation of new particle formation in subtropical urban environment, Atmos. Chem. Phys., 11, 3823-3833, doi:10.5194/acp-11-38232011, 2011.

Dal Maso, M., Kulmala M., Riipinen, I., Wagner, R., Hussein, T., Aalto, P. P., and Lehtinen, K. E. J.: Formation and growth of freshatmospheric aerosols: eight years of aerosol size distribution data from SMEAR II, Hyytiälä, Finland, Boreal Environ. Res., 10, 323-336, 2005.

de Gouw, J. and Warneke, C.: Measurements of volatile organic compounds in the earth's atmosphere using proton-transferreaction mass spectrometry, Mass Spectrom. Rev., 26, 223-257, 2007.

Fiedler, V., Dal Maso, M., Boy, M., Aufmhoff, H., Hoffmann, J., Schuck, T., Birmili, W., Hanke, M., Uecker, J., Arnold, F., and Kulmala, M.: The contribution of sulphuric acid to atmospheric particle formation and growth: a comparison between boundary layers in Northern and Central Europe, Atmos. Chem. Phys., 5, 1773-1785, doi:10.5194/acp-5-1773-2005, 2005.

Fuchs, N. A. and Sutugin, A. G.: Highly Dispersed Aerosols, Ann Arbor Science Publisher, Ann Arbor, 1970.

Gagné, S., Laakso, L., Petäjä, T., Keminen, V.-M., and Kulmala, M.: Analysis on one year of Ion-DMPS data from the SMEAR II station, Finland, Tellus B, 60, 318-329, 2008.

Gagné, S., Lehtipalo, K., Manninen, H. E., Nieminen, T., Schobesberger, S., Franchin, A., Yli-Juuti, T., Boulon, J., Sonntag, A., Mirme, S., Mirme, A., Hõrrak, U., Petäjä, T., Asmi, E., and Kulmala, M.: Intercomparison of air ion spectrometers: an evaluation of results in varying conditions, Atmos. Meas. Tech., 4, 805-822, doi:10.5194/amt-4-805-2011, 2011.

Guenther, A., Zimmerman, P., Harley, P., Monson, R., and Fall, R.: Isoprene and monoterpene emission rate variability: Model evaluations and sensitivity analyses, J. Geophys. Res., 98, 1260912617, 1993.

Hakola, H, Tarvainen, V., Laurila, T., Hiltunen, V., Hellen, H., and Keronen, P.: Seasonal variation of VOC concentrations above a boreal coniferous forest, Atmos. Environ., 37, 1623-1634, 2003.

Hamed, A., Joutsensaari, J., Mikkonen, S., Sogacheva, L., Dal Maso, M., Kulmala, M., Cavalli, F., Fuzzi, S., Facchini, M. C., Decesari, S., Mircea, M., Lehtinen, K. E. J., and Laaksonen, A.: Nucleation and growth of new particles in Po Valley, Italy, Atmos. Chem. Phys., 7, 355-376, doi:10.5194/acp-7-355-2007, 2007.

Hao, L. Q., Romakkaniemi, S., Yli-Pirilä, P., Joutsensaari, J., Kortelainen, A., Kroll, J. H., Miettinen, P., Vaattovaara, P., Tiitta, P., Jaatinen, A., Kajos, M. K., Holopainen, J. K., Heijari, J., Rinne, J., Kulmala, M., Worsnop, D. R., Smith, J. N., and Laaksonen, A.: Mass yields of secondary organic aerosols from the oxidation of $\alpha$-pinene and real plant emissions, Atmos. Chem. Phys., 11, 1367-1378, doi:10.5194/acp-11-1367-2011, 2011.

Hari, P. and Kulmala, M.: Station for measuring ecosystematmosphere relations (SMEAR II), Boreal Environ. Res., 10, 315-322, 2005
Hirsikko, A., Laakso, L., Hõrrak, U., Aalto, P. P., Kerminen, V.M., and Kulmala, M.: Annual and size dependent variation of growth rates and ion concentrations in boreal forest, Boreal Environ. Res., 10, 357-369, 2005.

Hirsikko, A., Nieminen, T., Gagné, S., Lehtipalo, K., Manninen, H. E., Ehn, M., Hõrrak, U., Kerminen, V.-M., Laakso, L., McMurry, P. H., Mirme, A., Mirme, S., Petäjä, T., Tammet, H., Vakkari, V., Vana, M., and Kulmala, M.: Atmospheric ions and nucleation: a review of observations, Atmos. Chem. Phys., 11, 767798, doi:10.5194/acp-11-767-2011, 2011.

Hõrrak, U., Tammet, H., Aalto, P. P., and Kulmala, M.: On the charge distribution on nanometer aerosol particles in the atmosphere during nucleation burst events at boreal forest, Helsinki, Report Series in Aerosol Science, 68, 94-99, 2004a.

Hõrrak, U., Tammet, H., Aalto, P. P., and Kulmala, M.: Charging state of nanometer aerosol particles in the atmosphere during nucleation burst events at boreal forest, in: Nucleation and Atmospheric Aerosols 2004: 16th International Conf., edited by Kasahara, M. and Kulmala, M., 307-310, 2004b.

Hussein, T., Dal Maso, M., Petäjä, T., Koponen, I. K., Paatero, P., Aalto, P. P., Hämeri, K., and Kulmala, M.: Evaluation of an automatic algorithm for fitting the particle number size distribution, Boreal Environ. Res., 10, 337-355, 2005.

Hyvönen, S., Junninen, H., Laakso, L., Dal Maso, M., Grönholm, T., Bonn, B., Keronen, P., Aalto, P., Hiltunen, V., Pohja, T., Launiainen, S., Hari, P., Mannila, H., and Kulmala, M.: A look at aerosol formation using data mining techniques, Atmos. Chem. Phys., 5, 3345-3356, doi:10.5194/acp-5-3345-2005, 2005.

Iida, K., Stolzenburg, M. R., McMurry, P. H., and Smith, J. N.: Estimating nanoparticle growth rates from size-dependent charged fractions: Analysis of the new particle formation events in Mexico City, J. Geophys. Res., 113, D05207, doi:10.1029/2007JD009260, 2008.

Jimenez, J. L., Canagaratna, M. R., Donahue, N. M., Prevot, A. S. H., Zhang, Q., Kroll, J. H., DeCarlo, P. F., Allan, J. D., Coe, H., Ng, N. L., Aiken, A. C., Docherty, K. S., Ulbrich, I. M., Grieshop, A. P., Robinson, A. L., Duplissy, J., Smith, J. D., Wilson, K. R., Lanz, V. A., Hueglin, C., Sun, Y. L., Tian, J., Laaksonen, A., Raatikainen, T., Rautiainen, J., Vaattovaara, P., Ehn, M., Kulmala, M., Tomlinson, J. M., Collins, D. R., Cubison, M. J., Dunlea, E. J., Huffman, J. A., Onasch, T. B., Alfarra, M. R., Williams, P. I., Bower, K., Kondo, Y., Schneider, J., Drewnick, F., Borrmann, S., Weimer, S., Demerjian, K., Salcedo, D., Cottrell, L., Griffin, R., Takami, A., Miyoshi, T., Hatakeyama, S., Shimono, A., Sun, J. Y., Zhang, Y. M., Dzepina, K., Kimmel, J. R., Sueper, D., Jayne, J. T., Herndon, S. C., Trimborn, A. M., Williams, L. R., Wood, E. C., Middlebrook, A. M., Kolb, C. E., Baltensperger, U., and Worsnop, D. R.: Evolution of organic aerosols in the atmosphere, Science, 326, 1525-1529, 2009.

Kerminen, V.-M. and Kulmala, M.: Analytical formulae connecting the "real" and the "apparent" nucleation rate and the nuclei number concentration for atmospheric nucleation events, J. Aerosol Sci., 33, 609-622, 2002.

Kerminen, V.-M., Lehtinen, K. E. J., Anttila, T., and Kulmala, M.: Dynamics of atmospheric nucleation mode particles: a timescale analysis, Tellus B, 56, 135-146, 2004.

Kristensson, A., Dal Maso, M., Swietlicki, E., Hussein, T., Zhou, J., Kerminen, V.-M., and Kulmala, M.: Characterization of new particle formation events at a background site in Southern Sweden: 
relation to air mass history, Tellus B, 60, 330-344, 2008.

Kuang, C., McMurry, P. H., McCormick, A. V., and Eisele, F. L.: Dependence of nucleation rates on sulfuric acid vapor concentration in diverse atmospheric locations, J. Geophys. Res., 113, D10209, doi:10.1029/2007JD009253, 2008.

Kuang, C., McMurry, P. H., and McCormick, A. V.: Determination of cloud condensation nuclei production from measured new particle formation events, Geophys. Res. Lett., 36, L09822, doi:10.1029/2009GL037584, 2009.

Kuang, C., Riipinen, I., Sihto, S.-L., Kulmala, M., McCormick, A. V., and McMurry, P. H.: An improved criterion for new particle formation in diverse atmospheric environments, Atmos. Chem. Phys., 10, 8469-8480, doi:10.5194/acp-10-8469-2010, 2010.

Kuang, C., Chen, M., Zhao, J., Smith, J., McMurry, P. H., and Wang, J.: First size-dependent growth rate measurements of 1 to $5 \mathrm{~nm}$ freshly formed atmospheric nuclei, Atmos. Chem. Phys. Discuss., 11, 25427-25471, doi:10.5194/acpd-11-25427-2011, 2011.

Kulmala, M., Toivonen, A., Mäkelä, J. M., and Laaksonen, A.: Analysis of the growth of nucleation mode particles observed in boreal forest, Tellus B, 50, 449-462, 1998.

Kulmala, M., Hämeri, K., Aalto, P. P., Mäkelä, J. M., Pirjola, L., Nilsson, E. D., Buzorius, G., Rannik, Ü., Dal Maso, M., Seidl, W., Hoffman, T., Janson, R., Hansson, H.-C., Viisanen, Y., Laaksonen, A., and O'Dowd, C. D.: Overview of the international project on biogenic aerosol formation in the boreal forest, Tellus B, 53, 324-343, 2001.

Kulmala, M., Kerminen, V.-M., Anttila, T., Anttila, T., Laaksonen, A., and O'Dowd, C. D.: Organic aerosol formation via sulphate cluster activation, J. Geophys. Res., 109, D04205, doi:10.1029/2003JD003961, 2004c.

Kulmala, M., Laakso, L., Lehtinen, K. E. J., Riipinen, I., Dal Maso, M., Anttila, T., Kerminen, V.-M., Hõrrak, U., Vana, M., and Tammet, H.: Initial steps of aerosol growth, Atmos. Chem. Phys., 4, 2553-2560, doi:10.5194/acp-4-2553-2004, 2004b.

Kulmala, M., Vehkamäki, H., Petäjä, T., Dal Maso, M., Lauri, A., Kerminen, V.-M., Birmili, W., and McMurry, P. H.: Formation and growth rates of ultrafine atmospheric particles: a review of observations, Aerosol Science, 35, 143-176, 2004a.

Kulmala, M., Petäjä, T., Mönkkönen, P., Koponen, I. K., Dal Maso, M., Aalto, P. P., Lehtinen, K. E. J., and Kerminen, V.-M.: On the growth of nucleation mode particles: source rates of condensable vapor in polluted and clean environments, Atmos. Chem. Phys., 5, 409-416, doi:10.5194/acp-5-409-2005, 2005.

Kulmala, M., Lehtinen, K. E. J., and Laaksonen, A.: Cluster activation theory as an explanation of the linear dependence between formation rate of $3 \mathrm{~nm}$ particles and sulphuric acid concentration, Atmos. Chem. Phys., 6, 787-793, doi:10.5194/acp-6-787-2006, 2006.

Kulmala, M., Mordas, G., Petäjä, T., Grönholm, T., Aalto, P. P., Vehkamäki, H., Hienola, A. I., Herrmann, E., Sipilä, M., Riipinen, I., Manninen, H. E., Hämeri, K., Stratmann, F., Bilde, M., Winkler, P. M., Birmili, W., and Wagner, P. E.: The condensation particle counter battery (CPCB): A new tool to investigate the activation properties of nanoparticles, J. Aerosol Sci., 38, 289-304, 2007.

Kulmala, M., Riipinen, I., Sipilä, M., Manninen, H. E., Petäjä, T., Junninen, H., Dal Maso, M., Mordas, G., Mirme, A., Vana, M., Hirsikko, A., Laakso, L., Harrison, R. M., Hanson, I., Leung, C.,
Lehtinen, K. E. J., and Kerminen, V.-M.: Toward direct measurement of atmospheric nucleation, Science, 318, 89-92, 2007.

Laakso, L., Petäjä, T., Lehtinen, K. E. J., Kulmala, M., Paatero, J., Hõrrak, U., Tammet, H., and Joutsensaari, J.: Ion production rate in a boreal forest based on ion, particle and radiation measurements, Atmos. Chem. Phys., 4, 1933-1943, doi:10.5194/acp-41933-2004, 2004.

Laakso, L., Gagné, S., Petäjä, T., Hirsikko, A., Aalto, P. P., Kulmala, M., and Kerminen, V.-M.: Detecting charging state of ultra-fine particles: instrumental development and ambient measurements, Atmos. Chem. Phys., 7, 1333-1345, doi:10.5194/acp-7-13332007, 2007a.

Laakso, L., Grönholm, T., Kulmala, L., Haapanala, S., Hirsikko, A., Lovejoy, E.R., Kazil, J., Kurtén, T., Boy, M., Nilsson, E.D., Sogachev, A., Riipinen, I., Stratmann, F., and Kulmala, M.: Hotair balloon as a platform for boundary layer profile measurements during particle formation, Boreal Environ. Res., 12, 279-294, 2007b.

Laaksonen, A., Kulmala, M., O’Dowd, C. D., Joutsensaari, J., Vaattovaara, P., Mikkonen, S., Lehtinen, K. E. J., Sogacheva, L., Dal Maso, M., Aalto, P., Petäjä, T., Sogachev, A., Yoon, Y. J., Lihavainen, H., Nilsson, D., Facchini, M. C., Cavalli, F., Fuzzi, S., Hoffmann, T., Arnold, F., Hanke, M., Sellegri, K., Umann, B., Junkermann, W., Coe, H., Allan, J. D., Alfarra, M. R., Worsnop, D. R., Riekkola, M. -L., Hyötyläinen, T., and Viisanen, Y.: The role of VOC oxidation products in continental new particle formation, Atmos. Chem. Phys., 8, 2657-2665, doi:10.5194/acp-82657-2008, 2008.

Lappalainen, H. K., Sevanto, S., Bäck, J., Ruuskanen, T. M., Kolari, P., Taipale, R., Rinne, J., Kulmala, M., and Hari, P.: Day-time concentrations of biogenic volatile organic compounds in a boreal forest canopy and their relation to environmental and biological factors, Atmos. Chem. Phys., 9, 5447-5459, doi:10.5194/acp-9-5447-2009, 2009.

Lehtinen, K. E. J. and Kulmala, M.: A model for particle formation and growth in the atmosphere with molecular resolution in size, Atmos. Chem. Phys., 3, 251-257, doi:10.5194/acp-3-251-2003, 2003.

Leppä, J., Anttila, T., Kerminen, V.-M., Kulmala, M., and Lehtinen, K. E. J.: Atmospheric new particle formation: real and apparent growth of neutral and charged particles, Atmos. Chem. Phys., 11, 4939-4955, doi:10.5194/acp-11-4939-2011, 2011.

Lindinger, W., Hansel, A., and Jordan, A.: Proton-transfer-reaction mass spectrometry (PTR-MS): on-line monitoring of volatile organic compounds at ppt levels, Chem. Soc. Rev., 27, 347-354, 1998.

Manninen, H. E., Nieminen, T., Asmi, E., Gagné, S., Häkkinen, S., Lehtipalo, K., Aalto, P., Vana, M., Mirme, A., Mirme, S., Hõrrak, U., Plass-Dülmer, C., Stange, G., Kiss, G., Hoffer, A., Törő, N., Moerman, M., Henzing, B., de Leeuw, G., Brinkenberg, M., Kouvarakis, G. N., Bougiatioti, A., Mihalopoulos, N., O’Dowd, C., Ceburnis, D., Arneth, A., Svenningsson, B., Swietlicki, E., Tarozzi, L., Decesari, S., Facchini, M. C., Birmili, W., Sonntag, A., Wiedensohler, A., Boulon, J., Sellegri, K., Laj, P., Gysel, M., Bukowiecki, N., Weingartner, E., Wehrle, G., Laaksonen, A., Hamed, A., Joutsensaari, J., Petäjä, T., Kerminen, V.-M., and Kulmala, M.: EUCAARI ion spectrometer measurements at 12 European sites - analysis of new particle formation events, Atmos. Chem. Phys., 10, 7907-7927, doi:10.5194/acp-10-7907- 
2010, 2010.

McMurry, P. H. and Wilson, J. C.: Growth laws for the formation of secondary ambient aerosol: Implications for chemical conversion mechanisms, Atmos. Environ., 16, 121-134, 1982.

Merikanto, J., Spracklen, D. V., Mann, G. W., Pickering, S. J., and Carslaw, K. S.: Impact of nucleation on global CCN, Atmos. Chem. Phys., 9, 8601-8616, doi:10.5194/acp-9-8601-2009, 2009.

Mirme, A., Tamm, E., Mordas, G., Vana, M., Uin, J., Mirme, S., Bernotas, T., Laakso, L., Hirsikko, A., and Kulmala, M.: A widerange multi-channel Air Ion Spectrometer, Boreal Environ. Res., 12, 247-264, 2007.

Mäkelä, J. M., Riihelä, M., Ukkonen, A., Jokinen, V., and Keskinen, J.: Comparison of mobility equivalent diameter with KelvinThomson diameter using ion mobility data, J. Chem. Phys., 105, 1562-1571, 1996.

Mäkelä, J. M., Dal Maso, M., Pirjola, L., Keronen, P., Laakso, L., Kulmala, M., and Laaksonen, A.: Characteristics of the atmospheric particle formation events observed at a boreal forest site in southern Finland, Boreal Environ. Res., 5, 299-313, 2000.

Neitola, K., Asmi, E., Komppula, M., Hyvärinen, A.-P., Raatikainen, T., Panwar, T. S., Sharma, V. P., and Lihavainen, $\mathrm{H}$.: New particle formation infrequently observed in $\mathrm{Hi}$ malayan foothills - why?, Atmos. Chem. Phys., 11, 8447-8458, doi:10.5194/acp-11-8447-2011, 2011.

Nieminen, T., Lehtinen, K. E. J., and Kulmala, M.: Sub-10 nm particle growth by vapor condensation - effects of vapor molecule size and particle thermal speed, Atmos. Chem. Phys., 10, 97739779, doi:10.5194/acp-10-9773-2010, 2010.

O'Dowd, C. D., Aalto, P., Hämeri, K., Kulmala, M., and Hoffmann, T.: Atmospheric particles from organic vapours, Nature, 416, 497-498, 2002.

Petäjä, T., Mauldin III, R. L., Kosciuch, E., McGrath, J., Nieminen, T., Paasonen, P., Boy, M., Adamov, A., Kotiaho, T., and Kulmala, M.: Sulfuric acid and $\mathrm{OH}$ concentrations in a boreal forest site, Atmos. Chem. Phys., 9, 7435-7448, doi:10.5194/acp9-7435-2009, 2009.

Pierce, J. R. and Adams, P. J.: Efficiency of cloud condensation nuclei formation from ultrafine particles, Atmos. Chem. Phys., 7, 1367-1379, doi:10.5194/acp-7-1367-2007, 2007.

Pirjola, L., Kulmala, M., Wilck, M., Bischoff, A., Stratmann, F., and Otto, E.: Formation of sulphuric acid aerosols and cloud condensation nuclei: an expression for significant nucleation and model comparison, J. Aerosol Sci., 30, 1079-1094, 1999.

Place Jr., P. F., Ziemba, L. D., and Griffin, R. J.: Observations of nucleation-mode particle events and size distributions at a rural New England site, Atmos. Environ., 44, 88-94, 2010.

Riipinen, I., Sihto, S.-L., Kulmala, M., Arnold, F., Dal Maso, M., Birmili, W., Saarnio, K., Teinilä, K., Kerminen, V.-M., Laaksonen, A., and Lehtinen, K. E. J.: Connections between atmospheric sulphuric acid and new particle formation during QUEST IIIIV campaigns in Heidelberg and Hyytiälä, Atmos. Chem. Phys., 7, 1899-1914, doi:10.5194/acp-7-1899-2007, 2007.

Riipinen, I., Manninen, H. E., Yli-Juuti, T., Boy, M., Sipilä, M., Ehn, M., Junninen, H., Petäjä, T., and Kulmala, M.: Applying the Condensation Particle Counter Battery (CPCB) to study the water-affinity of freshly-formed $2-9 \mathrm{~nm}$ particles in boreal forest, Atmos. Chem. Phys., 9, 3317-3330, doi:10.5194/acp-93317-2009, 2009.
Riipinen, I., Pierce, J. R., Yli-Juuti, T., Nieminen, T., Häkkinen, S., Ehn, M., Junninen, H., Lehtipalo, K., Petäjä, T., Slowik, J., Chang, R., Shantz, N. C., Abbatt, J., Leaitch, W. R., Kerminen, V.-M., Worsnop, D. R., Pandis, S. N., Donahue, N. M., and Kulmala, M.: Organic condensation: a vital link connecting aerosol formation to cloud condensation nuclei (CCN) concentrations, Atmos. Chem. Phys., 11, 3865-3878, doi:10.5194/acp-11-38652011, 2011.

Rohrer, F. and Berresheim, H.: Strong correlation between levels of tropospheric hydroxyl radicals and solar ultraviolet radiation, Nature, 442, 184-187, 2006.

Sihto, S.-L., Kulmala, M., Kerminen, V.-M., Dal Maso, M., Petäjä, T., Riipinen, I., Korhonen, H., Arnold, F., Janson, R., Boy, M., Laaksonen, A., and Lehtinen, K. E. J.: Atmospheric sulphuric acid and aerosol formation: implications from atmospheric measurements for nucleation and early growth mechanisms, Atmos. Chem. Phys., 6, 4079-4091, doi:10.5194/acp-6-4079-2006, 2006.

Sipilä, M., Berndt, T., Petäjä, T., Brus, D., Vanhanen, J., Stratmann, F., Patokoski, J., Mauldin III, R. L., Hyvärinen, A.-P., Lihavainen, H., and Kulmala, M.: The role of sulfuric acid in atmospheric nucleation, Science, 327, 1243-1246, 2010.

Smith, J. N., Dunn, M. J., VanReken, T. M., Iida, K., Stolzenburg, M. R., McMurry, P. H., and Huey, L. G.: Chemical composition of atmospheric nanoparticles formed from nucleation in Tecamac, Mexico: Evidence for an important role for organic species in nanoparticle growth, Geophys. Res. Lett., 35, L04808, doi:10.1029/2007GL032523, 2008.

Smith, J. N., Barsanti, K. C., Friedli, H. R., Ehn, M., Kulmala, M., Collins, D. R., Scheckman, J. H., Williams, B. J., and McMurry, P. H.: Observations of aminium salts in atmospheric nanoparticles and possible climatic implications, P. Natl. Aacad. Sci., 107, 6634-6639, 2010.

Sogacheva, L., Saukkonen, L., Nilsson, E. D., Dal Maso, M., Schultz, D., de Leeuw, G., and Kulmala, M.: New aerosol particle formation in different synoptic situations at Hyytiälä, southern Finland, Tellus B, 60, 485-494, 2008.

Solomon, S., Qin, D., Manning, M., Chen, Z., Marquis, M., Averyt, K. B., Tignor, M., and Miller, H. L (Eds.): Climate Change 2007: The Physical Science Basis, Cambridge University Press, 2007.

Spracklen, D. V., Carslaw, K. S., Kulmala, M., Kerminen, V.-M., Sihto, S.-L., Riipinen, I., Merikanto, J., Mann, G. W., Chipperfield, M. P., Wiedensohler, A., Birmili, W., and Lihavainen, H.: Contribution of particle formation to global cloud condensation nuclei concentrations, Geophys. Res. Lett., 35, L06808, doi:10.1029/2007GL033038, 2008

Stolzenburg, M. R., McMurry, P. H., Sakurai, H., Smith, J. N., Mauldin III, R. L., Eisele, F. L., and Clement, C. F.: Growth rates of freshly nucleated atmospheric particles in Atlanta, J. Geophys. Res., 110, D22S05, doi:10.1029/2005JD005935, 2005.

Suni, T., Kulmala, M., Hirsikko, A., Bergman, T., Laakso, L., Aalto, P. P., Leuning, R., Cleugh, H., Zegelin, S., Hughes, D., van Gorsel, E., Kitchen, M., Vana, M., Hõrrak, U., Mirme, S., Mirme, A., Sevanto, S., Twining, J., and Tadros, C.: Formation and characteristics of ions and charged aerosol particles in a native Australian Eucalypt forest, Atmos. Chem. Phys., 8, 129-139, doi:10.5194/acp-8-129-2008, 2008.

Svenningsson, B., Arneth, A., Hayward, S., Holst, T., Massling, A., Swietlicki, E., Hirsikko, A., Junninen, H., Riipinen, I., Vana, M., 
Dal Maso, M., Hussein, T., and Kulmala, M.: Aerosol particle formation events and analysis of growth rates observed above a subarctic wetland-forest mosaic, Tellus B, 60, 353-364, 2008.

Taipale, R., Ruuskanen, T. M., Rinne, J., Kajos, M. K., Hakola, H., Pohja, T., and Kulmala, M.: Technical Note: Quantitative long-term measurements of VOC concentrations by PTR-MS measurement, calibration, and volume mixing ratio calculation methods, Atmos. Chem. Phys., 8, 6681-6698, doi:10.5194/acp8-6681-2008, 2008.

Tammet, H.: Balance Scanning Mobility Analyzer BSMA, in: Nucleation and Atmsopheric Aerosols 2004, 16th International Conference, Kyoto 2004, edited by: Kasahara, M. and Kulmala, M., 294-297, 2004.

Tammet, H.: Continuous scanning of the mobility and size distribution of charged cluster and nanometer particles in atmospheric air and the Balanced Scanning Mobility Analyzer BSMA, Atmos. Res., 82, 523-535, 2006.

Tunved, P., Hansson, H.-C., Kerminen, V.-M., Ström, J., Dal Maso, M., Lihavainen, H., Viisanen, Y., Aalto, P. P., Komppula, M., and Kulmala, M.: High natural aerosol loading over boreal forests, Science, 312, 261-263, 2006.

Vakkari, V., Laakso, H., Kulmala, M., Laaksonen, A., Mabaso, D., Molefe, M., Kgabi, N., and Laakso, L.: New particle formation events in semi-clean South African savannah, Atmos. Chem. Phys., 11, 3333-3346, doi:10.5194/acp-11-3333-2011, 2011.

Venzac, H., Sellegri, K., Laj, P., Villani, P., Bonasoni, P., Marinoni, A., Cristofanelli, P., Calzolari, F., Fuzzi, S., Decesari, S., Facchini, M.-C., Vuillermoz, E., and Verza, G. P.: High frequency new particle formation in the Himalayas, P. Natl. Acad. Sci., 105, 15666-15671, 2008.

Virkkula, A., Hirsikko, A., Vana, M., Aalto, P. P., Hillamo, R., and Kulmala, M.: Charged particle size distributions and analysis of particle formation events at the Finnish Antarctic research station Aboa, Boreal Environ. Res., 12, 397-408, 2007.
Weber, R. J., McMurry, P. H., Eisele, F. L., and Tanner, D. J.: Measurement of expected nucleation precursor species and 3-500 nm diameter particles at Mauna Loa observatory, Hawaii, J. Atmos. Sci., 52, 2242-2257, 1995.

Weber, R. J., Marti, J. J., McMurry, P. H., Eisele, F. L., Tanner, D. J., and Jefferson, A.: Measurements of new particle formation and ultrafine particle growth rates at a clean continental site, J. Geophys. Res., 102, 4375-4385, 1997.

Wehner, B., Petäjä, T., Boy, M., Engler, C., Birmili, W., Tuch, T., Wiedensohler, A., and Kulmala, M.: The contribution of sulphuric acid and non-volatile compounds on the growth of freshly formed atmospheric aerosols, Geophys. Res. Lett., 32, L17810, doi:10.1029/2005GL023827, 2005.

Wu, Z., Hu, M., Liu, S., Wehner, B., Bauer, S., Ma Bling, A., Wiedensohler, A., Petäjä, T., Dal Maso, M., and Kulmala, M.: New particle formation in Beijing, China: Statistical analysis of a 1-year data set, J. Geophys. Res., 112, D09209, doi:10.1029/2006JD007406, 2007.

Yli-Juuti, T., Riipinen, I., Aalto, P. P., Nieminen, T., Maenhaut, W., Janssens, I. A., Claeys, M., Salma, I., Ocskay, R., Hoffer, A., Imre, K., and Kulmala, M.: Characteristics of new particle formation events and cluster ions at K-puszta, Hungary, Boreal Environ. Res., 14, 683-698, 2009.

Yue, D. L., Hu, M., Zhang, R. Y., Wang, Z. B., Zheng, J., Wu, Z. J., Wiedensohler, A., He, L. Y., Huang, X. F., and Zhu, T.: The roles of sulfuric acid in new particle formation and growth in the mega-city of Beijing, Atmos. Chem. Phys., 10, 4953-4960, doi:10.5194/acp-10-4953-2010, 2010. 